\title{
Hepatic gene expression profiles in juvenile rainbow trout (Oncorhynchus mykiss) fed fishmeal or fish oil-free diets
}

\author{
Stéphane Panserat ${ }^{1 *}$, Cathy Kolditz ${ }^{1}$, Nadège Richard ${ }^{1}$, Elisabeth Plagnes-Juan ${ }^{1}$, Francois Piumi ${ }^{2}$, \\ Diane Esquerré ${ }^{2,3}$, Francoise Médale ${ }^{1}$, Genevieve Corraze ${ }^{1}$ and Sadavisam Kaushik ${ }^{1}$ \\ ${ }^{1}$ INRA, UMR1067 Nutrition Aquaculture and Genomics, Pôle d'Hydrobiologie, CD 918, F-64310 Saint-Pée-sur-Nivelle, France \\ ${ }^{2} I N R A, D G A, U M R$ 314, Laboratoire de Radiobiologie et d'Etude du Génome, CRB GADIE, F-78350 Jouy-en-Josas, France \\ ${ }^{3}$ CEA, DSV, IRCM, SREIT, Laboratoire de Radiobiologie et d'Etude du Génome, F-78352 Jouy-en-Josas, France
}

(Received 30 November 2007 - Revised 25 February 2008 - Accepted 25 February 2008 - First published online 28 April 2008)

Reducing the reliance on fishery by-products as amino acid and fatty acid sources in feeds for farmed fish is a major objective today. We evaluated the effect of dietary fish oil or dietary fishmeal replacement by vegetable oils and plant proteins respectively through analysis of hepatic transcriptomes in rainbow trout (Oncorhynchus mykiss). Fish were fed right from first feeding with diets based on plant by-products before being killed. We analysed the hepatic gene profile using trout cDNA microarrays (9K). Our data showed that seventy-one and seventy-five genes were affected after fish oil and fishmeal replacement respectively. The major part of modified gene expression coding for proteins of the metabolic pathways was as follows: (i) a lower level of expression for genes of energy metabolism found in fish after fishmeal and fish oil replacement; (ii) a lower level of gene expression for fatty acid metabolism (biosynthesis) in fish fed with vegetable oils; (iii) a differential expression of actors of detoxification metabolism in trout fed with vegetable oils; (iv) a lower level of expression of genes involved in protein metabolism in fish fed with plant proteins. Overall, our data suggest that dietary fish oil replacement is linked to a decreased capacity of fatty acid biosynthesis (fatty acid synthase) and variation of detoxification metabolism (cytochrome P450s) whereas dietary fishmeal replacement may depress protein metabolism in the liver as reflected by glutamine synthetase.

Fish nutrition: Plant products: Fish oil: Fishmeal: Liver: Transcriptomics: Rainbow trout

Feed for intensively farmed fish still relies heavily on feedstuffs of marine origin, fishmeal and fish oil. This impairs the sustainability of fish production, while aquaculture should be a solution to the generally observed decline in fishery resources ${ }^{(1)}$. Research is intense for finding ways to replace marine feedstuffs (fishmeal and fish oil) by plant feedstuffs $^{(2)}$. In the past 20 years, fish feeds have included large amounts of fish oil, given the beneficial effects on $\mathrm{N}$ utilisation and environmental load ${ }^{(3,4)}$. Partial and total replacement of fishmeal by vegetable protein sources is similarly the object of several studies in almost all species ${ }^{(2,5)}$.

Efforts towards replacement of fishmeal by other alternative protein sources have been undertaken for more than two decades and there is a vast amount of literature on partial replacement of fishmeal by plant feedstuffs ${ }^{(6)}$. A number of disadvantages have been ascribed to the use of plant protein sources: relatively low protein content, amino acid imbalance, low palatability, presence of endogenous anti-nutritional factors and large amounts of carbohydrates ${ }^{(2,7,8)}$. Attempts have been made to develop fishmeal-free diets for different species including salmonids either with single ingredients duly supplemented with amino $\operatorname{acids}^{(9)}$ or using a mixture of different protein sources ${ }^{(10-13)}$. It is clear that a substantial reduction in the dietary levels of fishmeal can be achieved although total replacement of fishmeal by plant ingredients is still not common in salmonids. Some earlier studies have shown that total replacement of fishmeal by plant proteins leads to decreased growth of rainbow trout possibly linked to a modification of a number of hepatic metabolic pathways ${ }^{(14)}$.

Several studies with salmonids (rainbow trout, brown trout, Atlantic salmon, Pacific salmons) have shown that it is possible to replace fish oil by a single vegetable oil or mixture of vegetable oils without affecting growth or feed efficiencies ${ }^{(4,15)}$. Since the flesh fatty acid composition is known to be affected by the dietary fatty acid profiles, it is also known that once the fish are grown with vegetable oils over the major part of the life cycle, a finishing diet based on fish oil as the major lipid source can be used to tailor the final flesh fatty acid composition with the levels of n-3 PUFA (EPA and DHA) ideally suited for human nutrition and health ${ }^{(15-17)}$. The metabolic consequences are also numerous, mediated by a number of interacting pathways.

Abbreviations: FAS, fatty acid synthase; INRA, French National Institute for Agricultural Research; REST, Relative Expression Software tool; TMEV, TIGR Multiple Experiment Viewer.

* Corresponding author: Dr Stephane Panserat, fax +33 5595451 52, email panserat@st-pee.inra.fr 
The objective of the present study was to analyse the hepatic gene expression profile in rainbow trout (Oncorhynchus mykiss) fed over a long period diets with or without either fish oil or fishmeal, replaced respectively by a mixture of plant oils or plant proteins. We analysed specifically the liver since this is the main organ involved in nutrient utilisation as the centre of intermediary metabolism in animals. After transcriptomic analysis, differentially expressed genes were identified and some were specifically studied in rainbow trout liver following the plant-based diet intake.

\section{Experimental methods}

\section{Feeds, fish rearing and sampling}

Triploid rainbow trout were reared in the French National Institute for Agricultural Research (INRA) experimental fish farm at constant water temperature $\left(17 \pm 1^{\circ} \mathrm{C}\right)$ and under natural photoperiod conditions (Donzacq, Landes, France). To test the effect of fish oil replacement, fish were fed from first feeding to commercial size during 62 weeks with two isoproteic $(51 \%$ crude protein), isolipidic (30\% crude fat) and isoenergetic $(26 \mathrm{~kJ} / \mathrm{g})$ diets, differing only by the lipid source, i.e. either fish oil or a mixture of vegetable oils (30\% palm, $15 \%$ linseed, $55 \%$ rapeseed) as previously described $^{(18)}$ (Table 1).

To test the effect of fishmeal replacement, fish were fed from first feeding to commercial size during 52 weeks with two isonitrogenous, isolipidic and isoenergetic diets, differing only by the protein source, i.e. either fishmeal or a mixture of plant proteins (Table 2). These diets were produced by feed manufacturers (Nutreco, Stavanger, Norway and Le Gouessant Aquaculture, Lamballe, France, respectively).

Fish were randomly distributed into triplicate tanks per dietary treatment. Each diet was distributed by hand to visual satiation $6 \mathrm{~d}$ over $7 \mathrm{~d}$ and feed consumption was recorded every week. At the end of the growth trial, six fish from each group (two per tank) were randomly sampled $24 \mathrm{~h}$ after the last meal in order to have data following the long-term plant-diet adaptation. Fish were killed by a sharp blow to the head. Livers were weighed and immediately frozen in liquid $\mathrm{N}_{2}$ and kept at $-80^{\circ} \mathrm{C}$ pending analyses.

\section{Chemical composition of the diets}

The experimental diets were analysed using the following procedures. DM was determined after drying at $105^{\circ} \mathrm{C}$ for $24 \mathrm{~h}$. Gross energy was determined using an adiabatic bomb calorimeter (IKA; Heitersheim Gribheimer, Germany). Protein content $(\mathrm{N} \times 6.25)$ was determined by the Kjeldahl method after acid digestion. Total lipid content was determined by the method of Folch et al. ${ }^{(19)}$, after extraction by dichloromethane rather than chloroform. Fatty acid composition of the diets (and the whole body of fish fed with or without fish oil) was determined in the total lipid extract after acid-catalysed transmethylation as previously described ${ }^{(18)}$. Amino acid composition was determined after acid hydrolysis: amino acids were separated by ion-exchange chromatography using $\mathrm{pH}$ gradient elution followed by
Table 1. Composition of the diets used in the fish oil replacement studies*

\begin{tabular}{|c|c|c|}
\hline & FO diet & VO diet \\
\hline \multicolumn{3}{|l|}{ Ingredients (g/kg feed) } \\
\hline $\begin{array}{l}\text { Fishmeal (Scandinavian LT-fish meal; } \\
\text { Norsildmel, Norway) }\end{array}$ & $466 \cdot 9$ & $466 \cdot 9$ \\
\hline Maize gluten meal (Cargill, Staley, NC, USA) & $135 \cdot 2$ & $135 \cdot 2$ \\
\hline Soyabean meal (Denofa, Fredrikstad, Norway) & $100 \cdot 0$ & $100 \cdot 0$ \\
\hline Whole wheat (Statkorn, Oslo, Norway) & $46 \cdot 1$ & $46 \cdot 1$ \\
\hline Capelin oil (Nordsildmel, Norway) & $226 \cdot 8$ & - \\
\hline Rapeseed oil (Oelmuhle, Hamburg, Germany) & - & 124.7 \\
\hline Palm oil (Denofa, Fredrikstad, Norway) & - & 68.1 \\
\hline Linseed oil (Oliefabriek, Lictervelde, Belgium) & - & $34 \cdot 0$ \\
\hline Vitamin and mineral premixes $\dagger$ & $25 \cdot 0$ & $25 \cdot 0$ \\
\hline \multicolumn{3}{|l|}{ Analytical composition } \\
\hline DM $(\%)$ & $92 \cdot 2$ & 92.5 \\
\hline $\mathrm{CP}(\% \mathrm{DM})$ & $50 \cdot 9$ & $51 \cdot 3$ \\
\hline Crude fat (\% DM) & $29 \cdot 7$ & 29.5 \\
\hline Gross energy (kJ/g DM) & $26 \cdot 4$ & $26 \cdot 1$ \\
\hline \multicolumn{3}{|l|}{ Fatty acid composition ( $\mathrm{g} / 100 \mathrm{~g}$ total fatty acids) } \\
\hline $14: 0$ & 9.9 & $2 \cdot 0$ \\
\hline $16: 0$ & 13.4 & 19.5 \\
\hline $18: 0$ & 1.5 & $2 \cdot 7$ \\
\hline Total saturates & $26 \cdot 0$ & $25 \cdot 4$ \\
\hline $16: 1$ & $10 \cdot 0$ & 1.6 \\
\hline $18: 1$ & 14.4 & 39.9 \\
\hline $20: 1$ & $16 \cdot 6$ & $2 \cdot 0$ \\
\hline $22: 1$ & $10 \cdot 9$ & 1.6 \\
\hline Total monounsaturates & $52 \cdot 5$ & $45 \cdot 2$ \\
\hline $18: 2 n-6$ & 3.6 & $13 \cdot 7$ \\
\hline $20: 2 n-6$ & 0.2 & 0.06 \\
\hline $20: 4 n-6$ & 0.2 & 0.06 \\
\hline Total $n-6$ PUFA & 6.5 & 14.4 \\
\hline $18: 3 n-3$ & 0.8 & $10 \cdot 0$ \\
\hline $18: 4 n-3$ & $2 \cdot 3$ & 0.7 \\
\hline $20: 4 n-3$ & 0.3 & 0.1 \\
\hline $20: 5 n-3$ & 4.5 & 1.5 \\
\hline $22: 5 n-3$ & 0.3 & 0.1 \\
\hline $22: 6 n-3$ & 3.9 & 1.6 \\
\hline Total $n-3$ PUFA & $12 \cdot 2$ & 14.0 \\
\hline
\end{tabular}

FO diet, fish oil diet; VO, vegetable oil diet; CP, crude protein

* For further details, see Richard et al. (18). Diets were produced at Nutreco Technology Centre, Norway as extruded pellets.

† Mineral and vitamin premix according to National Research Council recommendations.

post-column derivatisation ninhydrin according to the method of Moore \& Stein ${ }^{(20)}$.

\section{cDNA microarrays}

Nylon microarrays were obtained from INRA-GADIE biological resources centre (Jouy-en-Josas, France; http://www-crb. jouy.inra.fr/). A total of 9023 rainbow trout cDNA originating from a pooled-tissue library ${ }^{(21)}$ plus 193 controls were spotted after PCR amplification. PCR products were spotted onto Hybond $\mathrm{N}+$ membranes as described by Nguyen et al. ${ }^{(22)}$. Positive (plant luciferase cDNA depot) and negative (water depot) controls were also spotted on each microarray.

\section{Hybridisation, scanning and quantification of microarrays}

Total RNA were extracted from rainbow trout liver using TRIzol ${ }^{\circledR}$ reagent (Invitrogen, Carlsbad, CA, USA). Four hepatic RNA samples corresponding to four individuals per 
Table 2. Composition of the diets used in the fishmeal replacement studies*

dietary group were used for microarray hybridisation at INRA UMR1067 transcriptomic facility (St-Pée-sur-Nivelle, France) according to the following procedure. RNA quality was determined using an Agilent bioanalyser. A first hybridisation was performed at $42^{\circ} \mathrm{C}$ for $48 \mathrm{~h}$ using $\gamma^{33} \mathrm{P}$-labelled $\mathrm{T} 7$ promoter oligonucleotide ( $5^{\prime}$-CACTATAGGGAATTTGGCC- $\left.3^{\prime}\right)$ to estimate the amount of cDNA in each spot. After stripping ( $3 \mathrm{~h}$ at $68^{\circ} \mathrm{C}, 0.1 \mathrm{X}$ SSC, $0.2 \% \mathrm{SDS}$ ), hybridisations with hepatic cDNA were performed. Microarrays were prehybridised for $1 \mathrm{~h}$ at $65^{\circ} \mathrm{C}$ in hybridisation buffer (5X Denhardt, 5X SSC, $0.5 \% \mathrm{SDS}$ ). Labelled cDNA were prepared from $5 \mu \mathrm{g}$ RNA by simultaneous reverse transcription and labelling for $1 \mathrm{~h}$ at $42^{\circ} \mathrm{C}$ in the presence of $1.85 \mathrm{MBq}(50 \mu \mathrm{Ci})[\alpha-33 \mathrm{P}] \mathrm{dCTP}$, $5 \mu \mathrm{M}$-cold dCTP and $800 \mu \mathrm{M}$ each of dATP, dGTP and dTTP and 200 units SuperScript ${ }^{\mathrm{TM}}$ III RT (Invitrogen) in $30 \mu \mathrm{l}$ final volume. A positive control corresponding to the luciferase mRNA (20 ng) (Promega, Madison, WI, USA) was simultaneously prepared. RNA was degraded by treatment at $68^{\circ} \mathrm{C}$ for $30 \mathrm{~min}$ with $10 \%$ SDS $(1 \mu \mathrm{l}), 0.5 \mathrm{M}$-EDTA $(1 \mu \mathrm{l})$ and $3 \mathrm{M}-\mathrm{NaOH}(3 \mu \mathrm{l})$ and then equilibrated at room temperature for $15 \mathrm{~min}$. Neutralisation was done by adding $1 \mathrm{M}$-2-amino-2-hydroxymethyl-propane-1,3-diol-HCl $(10 \mu \mathrm{l})$ and $2 \mathrm{M}-\mathrm{HCl}(3 \mu \mathrm{l})$. Microarrays were then incubated with the corresponding denatured labelled cDNA for $48 \mathrm{~h}$ at $65^{\circ} \mathrm{C}$ in hybridisation solution. After three washes $\left(1 \mathrm{~h}\right.$ at $68^{\circ} \mathrm{C}$ with $0.1 \mathrm{X} \mathrm{SSC}, 0.2 \% \mathrm{SDS}$ ), microarrays were exposed for
$65 \mathrm{~h}$ to phosphor-imaging plates that were scanned using a Fuji BAS-5000 (Fuji, Tokyo, Japan). Signal intensities were quantified using AGScan software (bioinformatic platform Sigenae; INRA; http://www.sigenae.org/) ${ }^{(23,24)}$.

\section{Microarray data analysis}

Data microarrays were deposited in BioArray Software Environment (BASE) database ${ }^{(25)}$, a 'minimum information about a microarray experiment' (MIAME) supportive customisable database available at the bioinformatic platform Sigenae. Signal processing was performed using vector oligonucleotide data to correct the relative amount of DNA present in each spot. At this step, low nucleotide signals (less than three times the background level) were excluded from the analysis. After correction, the signal was normalised by dividing each gene expression by the median value of the array before log transformation. Data were subsequently analysed using statistical TIGR Multiple Experiment Viewer software (TMEV; The Institute for Genomic Research, J. Craig Venter Institute, Rockville, MD, USA), which is a suite of microarray data analysis applications. Variation of gene expressions between two dietary treatments was termed significant when the $P$ value was $<0.01$ using the two-sample $t$ test for microarrays ${ }^{(26)}$ and followed by supervised hierarchical clustering for significant genes only. Organisation of genes for biological interpretation in the context of gene ontology was performed using GoMiner software (Genomics and Bioinformatics Group, National Institutes of Health, Bethesda, MD, USA; http://discover.nci.nih. gov/gominer//) ${ }^{(27)}$.

\section{Data mining}

Rainbow trout sequences originating from INRA Agenae ${ }^{(21)}$ and the US Department of Agriculture ${ }^{(28)}$ and expressed sequence tag (EST) sequencing programs were used to generate publicly available contigs (http://public-contigbrowser. sigenae.org:9090/index.html). The 4th version (om.4) was used for BlastX (version 4 (om.4); Basic Local Alignment Search Tool; http://www.ncbi.nlm.nih.gov/blast/) comparison. The score of each alignment was retrieved after performing a BlastX comparison.

\section{Real-time RT-PCR}

Gene expression levels were determined by real-time RT-PCR using six RNA including those used for microarray analysis. Total RNA $(1 \mu \mathrm{g})$ was reverse transcribed to cDNA with the Superscript $^{\mathrm{TM}}$ III RNAse H RT kit (Invitrogen, Carlsbad, CA, USA) using oligo dT primers. Real-time PCR was performed in the iCycler iQ ${ }^{\mathrm{TM}}$ (Bio-Rad, Hercules, CA, USA). Quantitative PCR analyses for gene expressions were performed on $10 \mu \mathrm{l}$ of the RT reaction mixture using the $\mathrm{iQ}^{\mathrm{TM}} \mathrm{SYBR}^{\circledR}$ Green Supermix (Bio-Rad). The total volume of the PCR reaction was $25 \mu \mathrm{l}$ containing $200 \mathrm{nM}$ of each primer. Primers were designed so that they were overlapping an intron when it was possible (Primer3 software; http://biotools.umassmed.edu/ bioapps/primer3_www.cgi) using known sequences in nucleotide databases (Table 3). 
Thermal cycling was initiated with the incubation at $95^{\circ} \mathrm{C}$ for 90 s for hot-start iTaq ${ }^{\mathrm{TM}}$ DNA polymerase activation. Thirty-five steps of PCR were performed, each one consisting of heating at $95^{\circ} \mathrm{C}$ for $20 \mathrm{~s}$ for denaturing, and at $59^{\circ} \mathrm{C}$ for $30 \mathrm{~s}$ for annealing and extension. Following the final cycle of the PCR, melting curves were systematically monitored (with a gradient of $0 \cdot 5^{\circ} \mathrm{C}$ per $10 \mathrm{~s}$ from 55 to $94^{\circ} \mathrm{C}$ ) to ensure that only one fragment was amplified. Samples without RT and samples without RNA were run for each reaction as negative controls.

\section{Data analysis}

Data are presented as mean values and standard deviations. We analysed the effects of the different diets with an unpaired two-tailed Student's $t$ test (Systat 9 software products; SPSS, Inc., Chicago, IL, USA), except for microarray data (see before) and quantitative RT-PCR data. For the latter, significant differences were considered at $P<0 \cdot 05$. Relative quantification of the target gene transcript with the efl $\alpha$ reference gene transcript ${ }^{(29)}$ was made following the Pfaffl method with the Relative Expression Software tool (RESTC) ${ }^{(30,31)}$. This mathematical algorithm computes an expression ratio, based on real-time PCR efficiency and the crossing point deviation of the unknown sample $v$. a control group:

$$
\begin{aligned}
\mathrm{R}= & \left(\left(\mathrm{E}_{\text {target gene }}\right)_{\text {target gene }}^{\Delta \mathrm{CT}(\text { mean control-mean unknown sample })}\right) / \\
& \left(\left(\mathrm{E}_{\mathrm{EF} 1 \alpha}\right)_{\mathrm{EF} 1 \alpha}^{\Delta \mathrm{CT}(\text { mean control-mean unknown sample })}\right),
\end{aligned}
$$

where E is PCR efficiency determined by standard curves using serial dilution of cDNA (cDNA dilutions from 1/16 up to $1 / 512), \Delta \mathrm{CT}$ being the crossing point deviation of an unknown sample $v$. a control. Statistical differences in gene expression between control and sample were evaluated in group means by randomisation tests ${ }^{(31)}$ using REST (C) software. A total of 2000 random allocations were performed and significant differences were considered at $P<0 \cdot 05$.

\section{Results}

Fish rearing and endpoint analysis: growth rate, feed efficiencies and whole-body composition

In the fish fed with fish oil and vegetable oils, growth performance was similar throughout the long-term study irrespective of dietary treatment; at the end of the growth study the two groups reached a final body weight of about $1 \mathrm{~kg}$ (see Richard et al. ${ }^{(18)}$ for further details). No differences were found in feed efficiency, protein feed efficiency and feed intake (Table 4). As it is well known that replacement of fish oil by vegetable oils may produce major changes in fatty acid composition of fish, we also analysed the whole-body fatty acid composition for the fish oil- and vegetable oil-fed fishes (Table 5); the whole-body fatty acid composition reflected largely the composition of the diet (Table 1). The fish fed vegetable oils exhibited the highest levels of $18: 1,18: 2 n-6$ and $18: 3 n-3$, whereas the fish fed the fish oil diet had a very high percentage of long-chain MUFA (14.1\% for $20: 1$ and $6.9 \%$ for $22: 1$ ) and also the highest proportion of EPA and DHA (2.4 and $5.2 \%$ respectively). In contrast to the fish fed with vegetable oils, trout fed with plant proteins had 
Table 4. Effects of fish oil replacement on growth performance and feed efficiency in juvenile rainbow trout over 62 weeks (initial body weight (IBW) $0.120 \mathrm{~g})^{\star}$

(Mean values and standard deviations for three tanks)

\begin{tabular}{lcccccc}
\hline & \multicolumn{2}{c}{ FO diet } & & \multicolumn{2}{c}{ VO diet } \\
\cline { 2 - 3 } & Mean & SD & & Mean & SD \\
\hline FBW $(\mathrm{g})$ & 1011 & 40 & & 1019 & 63 \\
Daily growth index $\dagger$ & 1.85 & 0.08 & & 1.85 & 0.15 \\
Feed efficiency $¥$ & 0.95 & 0.04 & & 0.95 & 0.08 \\
Protein efficiency ratio§ & 1.86 & & 0.07 & & 1.86 & 0.15 \\
\hline
\end{tabular}

FO diet, fish oil diet; VO, vegetable oil diet; FBW, final body weight.

* There was no significant difference between the groups $(P>0.05$; Student's $t$ test).

†Daily growth index $=100 \times\left(\mathrm{FBW}^{1 / 3}-\mathrm{IBW}^{1 / 3}\right) /$ duration $(49 \mathrm{~d})$.

$\ddagger$ Feed efficiency $=$ wet weight gain $(\mathrm{g}) /$ dry feed intake $(\mathrm{g})$.

$\S$ Protein efficiency ratio $=$ wet weight gain $(\mathrm{g}) /$ crude protein intake $(\mathrm{g})$.

significantly lower growth rates, lower feed efficiency and lower protein feed efficiency than fish fed with fishmeal $(P<0.05$; Student's $t$ test) (Table 6), even though the feed intake was higher in the fish fed vegetable proteins. These data suggest a low capacity of metabolic adaptation of the fish fed with plant proteins from first feeding.

Differentially expressed genes in the liver of rainbow trout linked to diet composition

Analysis of microarray data showed that almost $0.8 \%$ of genes were differentially expressed in our two experimental comparisons: (i) between the fish fed fish oil and vegetable oils, and (ii) between the fish fed fishmeal and plant proteins (Tables 7-10) $(P<0 \cdot 01, t$ test; TMEV). Among the seventy-one genes differentially expressed between the fish

Table 5. Effect of fish oil replacement on mean fatty acid composition of whole-body lipids after feeding the experimental diets for 62 weeks

\begin{tabular}{|c|c|c|}
\hline $\begin{array}{l}\text { Fatty acid composition } \\
\text { (g/100 g total fatty acids) }\end{array}$ & $\begin{array}{l}\text { FO diet } \\
(n 3)\end{array}$ & $\begin{array}{l}\text { VO diet } \\
\text { (n } 3)\end{array}$ \\
\hline $14: 0$ & 7.93 & $1 \cdot 80^{*}$ \\
\hline $16: 0$ & $16 \cdot 03$ & $17 \cdot 26$ \\
\hline $18: 0$ & 2.08 & 2.91 \\
\hline Total saturates & $26 \cdot 97$ & $22 \cdot 70^{*}$ \\
\hline $16: 1$ & $9 \cdot 45$ & $2 \cdot 41^{*}$ \\
\hline $18: 1$ & 21.56 & $41 \cdot 41^{*}$ \\
\hline $20: 1$ & $14 \cdot 11$ & $3 \cdot 39^{*}$ \\
\hline $22: 1$ & $6 \cdot 85$ & $1.63^{*}$ \\
\hline Total monounsaturates & $52 \cdot 26$ & $48 \cdot 93^{*}$ \\
\hline $18: 2 n-6$ & 4.48 & $12 \cdot 78^{*}$ \\
\hline $20: 2 n-6$ & 0.29 & 0.60 \\
\hline $20: 4 n-6$ & 0.16 & 0.16 \\
\hline Total $n-6$ PUFA & 5.04 & $13 \cdot 72^{*}$ \\
\hline $18: 3 n-3$ & 1.03 & $6.97^{\star}$ \\
\hline $18: 4 n-3$ & $1 \cdot 12$ & 0.75 \\
\hline $20: 4 n-3$ & 0.70 & 0.54 \\
\hline $20: 5 n-3$ & $2 \cdot 38$ & $0.97^{*}$ \\
\hline $22: 5 n-3$ & 0.64 & 0.36 \\
\hline $22: 6 n-3$ & $5 \cdot 16$ & $3.43^{*}$ \\
\hline Total $n-3$ PUFA & $11 \cdot 20$ & $13 \cdot 57^{*}$ \\
\hline
\end{tabular}

FO diet, fish oil diet; VO, vegetable oil diet.

*Mean value was significantly different from that of the fish fed the FO diet $(P<0.05)$
Table 6. Effects of fishmeal replacement on growth performance and feed efficiency in juvenile rainbow trout over 52 weeks (initial body weight (IBW) $0.215 \mathrm{~g}$ )

(Mean values and standard deviations for three tanks)

\begin{tabular}{|c|c|c|c|c|c|}
\hline & \multicolumn{2}{|c|}{ FM diet } & \multicolumn{2}{|c|}{ PP diet } & \multirow[b]{2}{*}{$P^{*}$} \\
\hline & Mean & SD & Mean & SD & \\
\hline FBW (g) & 775 & 26 & 659 & 24 & 0.005 \\
\hline Daily growth index† & $2 \cdot 35$ & 0.02 & $2 \cdot 22$ & 0.03 & 0.003 \\
\hline Feed efficiency $\ddagger$ & 1.06 & 0.02 & 0.95 & 0.03 & 0.01 \\
\hline Protein efficiency ratioß & $2 \cdot 71$ & 0.06 & $2 \cdot 28$ & 0.07 & 0.002 \\
\hline
\end{tabular}

FM diet, fishmeal diet; PP diet, plant-protein diet; FBW, final body weight.

*By Student's $t$ test.

† Daily growth index $=100 \times\left(\mathrm{FBW}^{1 / 3}-\mathrm{IBW}^{1 / 3}\right) /$ duration $(49 \mathrm{~d})$

$\ddagger$ Feed efficiency $=$ wet weight gain $(\mathrm{g}) /$ dry feed intake $(\mathrm{g})$.

$\S$ Protein efficiency ratio = wet weight gain $(\mathrm{g}) /$ crude protein intake $(\mathrm{g})$.

fed with fish oil and those fed with vegetable oils, sixteen and fifty-five hepatic transcripts exhibited, in the fish fed with vegetable oils, higher and lower abundance respectively (Tables 7 and 8). Moreover, among the seventy-five genes differentially expressed between the fish fed with fishmeal and those fed with plant protein, fifteen and sixty hepatic transcripts exhibited respectively higher or lower abundance in the fish fed with plant proteins (Tables 9 and 10).

\section{Biological significance of the results: data clustering and gene ontology}

We researched the significance of our data analysing some genes expressed in the clusters linked to specific biological process (Figs. 1 and 2). First, for the fish fed with or without fish oil, we observed three main clusters after analysing gene expression (Fig. 1 (a)). Cluster I was composed of numerous genes playing key roles in lysosomal and proteasomal proteolysis (cathepsins B and D, subunit of proteasomes) which were more expressed in the fish fed with vegetable oils $(P<0.01, t$ test; TMEV). We found also in this cluster one gene, CYP1A3, involved in xenobiotic metabolism. Cluster II was found to be mainly composed of genes involved in intermediary metabolism especially energy metabolism (succinate dehydrogenase, ubiquinol dehydrogenase) and lipid metabolism (fatty acid synthase (FAS) and long-chain fatty acid elongase). In this cluster, some genes also play roles in mRNA processing (splicing, maturation) (for details see Fig. 1 (b)). All the genes in cluster II were expressed at a lower level in the fish fed with vegetable oils $(P<0 \cdot 01, t$ test; TMEV). Finally, cluster III was mainly composed of genes involved in cell growth and maintenance (keratin, kindlin, actin): they were expressed at a higher level in the fish fed with vegetable oils than in those fed the fish oil-based diet $(P<0 \cdot 01, t$ test; TMEV). Overall, after dietary fish oil replacement by a blend of vegetable oils, a number of genes involved in lipid metabolism (lipogenesis, steroid synthesis, xenobiotic detoxification), protein catabolism, and transcription regulation were detected by gene ontology analysis (Table 11).

Second, for the fish fed with plant proteins and fishmeal, four clusters were detected (Fig. 2 (a)). Whereas cluster I was composed of miscellaneous genes, cluster III was linked 
Table 7. Hepatic transcripts exhibiting higher abundance in fish fed with vegetable oils after microarray analysis*

\begin{tabular}{|c|c|c|c|}
\hline Clone name & Sigenae contig $†$ & Swissprot-hit description & $P$ \\
\hline tcay0031b.c. 17 & tcay0025b.p.18_3.1.om.4 & FXN2_HUMAN Human T-cell leukemia virus enhancer factor & $6.9 \times 10^{-6}$ \\
\hline tcba0021c.m.22 & tcay0011b.k.02_5.1.om.4 & ZN41_HUMAN Zinc finger protein 41 & 0.001 \\
\hline 1RT149015_A_H08 & 15021467.1.om.4 & SNXN_HUMAN Sorting nexin 23 & 0.002 \\
\hline tcay0011b.d.05 & 15029633.1.om.4 & AR1A_HUMAN Actin-related protein $2 / 3$ complex subunit $1 \mathrm{~A}$ & 0.004 \\
\hline tcak0001a.e.11 & tcad0004a.b.23_3.1.om.4 & IF39_HUMAN Eukaryotic translation initiation factor 3 subunit 9 & 0.006 \\
\hline tcbk0041c.m.02 & tcbk0041c.m.02_5.1.om.4 & DLX6_BRARE Homeobox protein DLX-6 & 0.006 \\
\hline tcac0002c.h.01 & AF267126.1.om.4 & CP3R_ONCMY Cytochrome P450 3A27 (EC 1.14.14.1) & 0.007 \\
\hline tcay0038b.c.08 & tcay0036b.l.02_3.1.om.4 & CSP7_HUMAN Cofactor required for Sp1 transcriptional activation subunit 7 & 0.007 \\
\hline 1RT88C17_A_B09 & 15026549.1.om.4 & MPP5_HUMAN MAGUK p55 subfamily member 5 & 0.007 \\
\hline tcbk0019c.d. 07 & tcbk0019c.d.07_5.1.om.4 & UNKNOWN & 0.007 \\
\hline tcbk0036c.i.08 & tcay0036b.p.22_5.1.om.4 & LPB1_HUMAN Liprin-beta 1 & 0.007 \\
\hline tcad0001a.b.13 & tcad0001a.b.13_5.1.om.4 & CRBA_DROME Cyclic-AMP response element binding protein A & 0.008 \\
\hline tcbk0026c.f.15 & tcay0015b.j.03_3.1.om.4 & K1CR_XENLA Keratin & 0.008 \\
\hline tcbk0003c.k.15 & tcbk0003c.k.15_5.1.om.4 & YB85_YEAST Hypothetical $124.0 \mathrm{kDa}$ protein in PBP2-ABD1 intergenic region & 0.009 \\
\hline tcay0031b.d.23 & tcay0031b.d.23_3.1.om.4 & URP1_MOUSE Unc-112 related protein 1 (Kindlin-1) (Fragment) & 0.009 \\
\hline tcbk0026c.d.10 & 17236272.2.om.4 & MUSC_HUMAN Musculin & 0.009 \\
\hline
\end{tabular}

* Where $P<0.01$ by $t$ test (TIGR Multiple Experiment Viewer software; The Institute for Genomic Research, J. Craig Venter Institute, Rockville, MD, USA). The sixteen genes are classified following the $P$ values.

† http://public-contigbrowser.sigenae.org:9090/index.html

to intermediary metabolism, especially energy metabolism (quinone oxidoreductase, ubiquinol reductase), amino acid metabolism (arginase) and amino acid transport. Cluster II and cluster IV, even though also associated with metabolism, were focused on protein metabolism respectively with proteolytic (cathepsin, proteasome) and proteosynthetic (eight ribosomal proteins) pathways (for details, see Fig. 2 (b)). Clusters II, III and IV were composed of genes that were expressed much less in the fish fed with plant proteins $(P<0.01, t$ test; TMEV). Globally, the replacement of fishmeal by the plant protein sources indeed leads to a large number of genes involved in protein and amino acid metabolism being revealed by the gene ontology analysis (Table 12).

\section{Focus on specific differentially expressed genes}

We focused the present study on specific genes that can illustrate the major pathways modified by the diet variation on rainbow trout liver. In the context of dietary fish oil replacement, five genes involved in proteolysis (cathepsin), energy metabolism in mitochondria (ubiquinol cytochrome $\mathrm{c}$ reductase), lipid metabolism (FAS and long-chain fatty acid CoA ligase) and detoxification metabolism (cytochromes P450) have been selected (Table 13). Using six individuals per dietary group and the quantitative RT-PCR, except for the cathepsin D, we confirmed that cathepsin $\mathrm{B}$, ubiquinol cytochrome c reductase, FAS and cytochrome P4501A3 were expressed less in the fish fed with vegetable oils $(P<0.05$; REST test $)$. Moreover, we also checked that the cytochrome P4503A4 was more highly expressed in the liver of the fish fed with vegetable oils $(P<0.05$; REST test). Also, in the context of dietary fishmeal replacement, genes involved in proteosynthesis (ribosomal proteins) and amino acid metabolism (glutamine synthetase) were selected to be analysed by quantitative RT-PCR (Table 14). We confirmed by quantitative RT-PCR that the expression of the glutamine synthetase gene was lower in the livers of the fish fed with plant proteins than in those fed fishmeal $(P<0.05$; REST test): we analysed more precisely three glutamine synthase paralogous genes by specific amplification of the isoforms and we confirmed that GS01 and GS03 gene expressions were depressed by almost 7-fold in these fish. However, all the analysed genes coding for ribosomal proteins (four genes coding for ribosomal proteins of the 40S (6S and 7S) and 60S (L27 and L35) subunits) were not differentially expressed $(P>0 \cdot 05$; REST test): these latter results did not confirm the microarray data.

\section{Discussion}

\section{Overview}

In the present study, the substitution of dietary fishmeal by vegetable proteins seems to have some adverse consequences on fish growth whereas no differences were found in fish fed vegetable oils as previously observed ${ }^{(13,14,18)}$. This is the first ever set of nutrigenomics data in fish fed diets devoid of either fish oil or fishmeal. Analysis of the hepatic transcriptomes revealed that less than 100 genes were differentially expressed between all the nutritional conditions $(<1 \%)$, which is a relatively low number of differentially expressed genes. Two possible explanations are (i) that the cDNA microarray used in the present study is a generic rainbow trout cDNA tool (issue from 9023 cDNA extracted from different tissues at different developmental stages ${ }^{(21)}$ ), and not a specific rainbow trout liver cDNA microarray; and (ii) that although the diets differed in terms of ingredients (marine $v$. plant origins), they were not drastically different in terms of proximate composition (Tables 1-3). It is also interesting to note that when we analysed globally the data about differentially expressed genes, we observed no common genes between the two sets of experiments, with enrichment of differentially expressed genes in lipid metabolism and protein metabolism after fish oil and fishmeal replacements respectively. This suggests that the modification of liver transcriptomes was highly dependent of the origin of the ingredient, i.e. vegetable oil and plant proteins. Thus, in the following discussion, we will analyse separately the data from the two nutritional experiments by focusing on specific molecular actors. 
Table 8. Hepatic transcripts exhibiting lower abundance in fish fed with vegetable oils after microarray analysis*

\begin{tabular}{|c|c|c|c|}
\hline Clone name & Sigenae contig $\dagger$ & Swissprot-hit description & $P$ \\
\hline 1RT121N04_D_G02 & 15060218.1.om.4 & MAFK_MOUSE Transcription factor MafK & $1.36 \times 10^{-4}$ \\
\hline 1RT156K02_C_F01 & 15078821.1.om.4 & ROAA_MOUSE Heterogeneous nuclear ribonucleoprotein A/B & $2.07 \times 10^{-4}$ \\
\hline 1RT67M18_C_G09 & tcad0003a.n.17_3.1.om.4 & $\begin{array}{l}\text { DHSB_HUMAN Succinate dehydrogenase [ubiquinone] } \\
\text { iron-sulfur protein }\end{array}$ & $3.26 \times 10^{-4}$ \\
\hline tcba0008c.g.18 & tcba0008c.g.18_5.1.om.4 & SYN_HUMAN Asparaginyl-tRNA synthetase & $3.84 \times 10^{-4}$ \\
\hline tcba0003c.g.01 & tcba0003c.g.01_5.1.om.4 & TERA_RAT Transitional endoplasmic reticulum ATPase & $4.03 \times 10^{-4}$ \\
\hline 1RT77M23_A_G12 & 15025059.1.om.4 & SGK3_HUMAN Serine/threonine-protein kinase Sgk3 (EC 2.7.1.37) & $6.54 \times 10^{-4}$ \\
\hline 1RT80C06_C_B03 & 15026055.1.om.4 & ANXD_HUMAN Annexin A13 & 0.001 \\
\hline tcag0002b.n.03 & AF059711.1.om.4 & CP13_ONCMY Cytochrome P450 1A3 (EC 1.14.14.1) & 0.001 \\
\hline tcad0006a.f.22 & tcad0006a.f.22_3.1.om.4 & $\begin{array}{l}\text { PRSX_HUMAN } 26 \text { S protease regulatory subunit S10B } \\
\text { (Proteasome subunit p42) }\end{array}$ & 0.002 \\
\hline tcba0014c.h.05 & tcay0018b.k.17_3.1.om.4 & HS47_CHICK 47 kDa heat shock protein precursor & 0.002 \\
\hline
\end{tabular}

tcab0001c.e.06 1RT121J10_D_E05 1RT122N23_B_G12 tcba0018c.g.23 1RT108I09_A_E05 1RT34K04_C_F02 1RT114N22_D_G11 1RT54E07_A_C04 1RT65M18_C_G09

1RT106E04_C_C02 1RT158E21_A_C11 tcay0009b.b.09 1RT160F10_D_C05 1RT49M06_C_G03

1RT77N13 B G07 1RT78F08_D_C04 1RT85P10_D_H05 1RT121P18_D_H09 1RT121E14_C_C07 1RT146D15 B B08 1RT116G12 C_D06 1RT95I04_C_E02

tcbk0025c.b.12 1RT130F18_D_C09 tcay0001b.e. 11

1RT80E07_A_C04 1RT135H16_D_D08 tcad0001a.i.06 tcad0006a.g.21 1RT101L17 B F09 1RT138J19_B_E10 1RT103A16 C A08 1RT126E19_A_C10 1RT148G07_A_D04 1RT151H09_B_D05 1RT132N07_B_G04

1RT140L18_D_F09 1RT75D05_B_B03 tcbk0032c.i.16

1RT108E12_C_C06 1RT116C04_C_B02 tcay0027b.m.22 1RT62D24_D_B12 1RT41M15 A G08 tcac0002c.p.03 tcay0018b.k.17_3.1.om.4
tcab0001c.e.06_5.1.om.4
15018967.1.om.4
15017668.1.om.4
tcba0018c.g.23_5.1.om.4
15061441.1.om.4
15076953.1.om.4
15066941.1.om.4
15022193.1.om.4
15023915.1.om.4

tcad0002a.a.16_3.1.om.4 15089300.1.om. 4 tcay0023b.g.13_3.1.om.4 tcad0003a.I.14_5.1.om.4 15080981.1.om.4

15025133.1.om. 4 15025579.1.om. 4 15015655.1.om.4 tcad0002a.f.16 3.1.om.4 15063507.1.om.4 tcay0029b.b.09_5.1.om.4 15026944.1.om.4 tcad0007a.c.03_3.1.om.4

tcbk0004c.f.11_5.1.om.4 6187098.1.om.4 tcay0028b.l.18_3.1.om.4

tcav0003c.j.08_3.1.om.4 15029400.1.om. 4 tcad0001a.i.06_3.1.om.4 tcad0006a.g.21_3.1.om.4 tcay0032b.m.12_3.1.om.4 15064382.1.om. 4 tcad0003a.m.01_3.1.om.4 15019695.1.om.4 15015121.1.om. 4 15021715.1.om.4 tcay0027b.I.03_3.1.0m.4

15020168.1.om. 4 15024751.1.om. 4 tcav0001c.d.12_5.1.om.4

15020717.1.om. 4 tcad0001a.p.06 3.1.om. 4 tcay0020b.d.06_3.1.om.4 15023633.1.om.4 15077566.1.om. 4 15014607.1.om.4
HS47_CHICK $47 \mathrm{kDa}$ heat shock protein precursor

(Collagen-binding protein 1)

FAS_CHICK Fatty acid synthase (EC 2.3.1.85)

UNKNOWN

LCF4_RAT Long-chain-fatty-acid-CoA ligase 4 (EC 6.2.1.3)

UNKNOWN

EGL1_HUMAN Egl nine homolog 1 (EC 1.14.11.-)

ELK3_MOUSE ETS-domain protein Elk-3

SARA_HUMAN GTP-binding protein SAR1a

UNKNOWN

T9S3_HUMAN Transmembrane 9 superfamily protein member

3 precursor

PR39 YEAST Pre-mRNA processing protein PRP39

PUB1_SCHPO Ubiquitin-protein ligase pub1 (EC 6.3.2.-)

YCD1_HUMAN Hypothetical protein CGI-131

KCY PIG UMP-CMP kinase (EC 2.7.4.14)

YMNO_YEAST Hypothetical 65.0 kDa protein in COX14-COS3

intergenic region precursor

PGS2 HORSE Decorin precursor

UNKNOWN

TBA ONCKE Tubulin alpha chain

NFX1_HUMAN Transcriptional repressor NF-X1 (EC 6.3.2.-)

THA1_MOUSE THAP domain protein 1

HS47 CHICK $47 \mathrm{kDa}$ heat shock protein precursor

SMD2 HUMAN Small nuclear ribonucleoprotein Sm D2

VATL_HUMAN Vacuolar ATP synthase $16 \mathrm{kDa}$ proteolipid subunit (EC 3.6.3.14)

FAS_ANSAN Fatty acid synthase (EC 2.3.1.85)

TCPB_HUMAN T-complex protein 1

DD15_MOUSE Putative pre-mRNA splicing factor RNA

helicase

YE6A SCHPO Hypothetical protein C6G10.10c in chromosome I 0.006

PNPO MOUSE Pyridoxine-5'-phosphate oxidase (EC 1.4.3.5)

$\begin{array}{ll}\text { RSP6_CHLRE Flagellar radial spoke protein } 6 & 0.007\end{array}$

GCSP MOUSE Glycine dehydrogenase $\quad 0.007$

NEK1_HUMAN Serine/threonine-protein kinase Nek1 (EC 2.7.1.37) $\quad 0.007$

HP28_RAT 28 kDa heat- and acid-stable phosphoprotein $\quad 0.007$

CATD CLUHA Cathepsin D precursor (EC 3.4.23.5)

KLF4_MOUSE Kruppel-like factor $4 \quad 0.008$

SYQ_HUMAN Glutaminyl-tRNA synthetase (EC 6.1.1.18) 0.008

ACS1 RHIME Acetyl-coenzyme A synthetase 1 (EC 6.2.1.1) 0.008

PGBM_HUMAN Basement membrane-specific heparan 0.008

sulfate proteoglycan core protein precursor

SHO2 HUMAN Leucine-rich repeat protein SHOC-2

G2A_MOUSE Lysophosphatidylcholine receptor G2A $\quad 0.009$

UCR2 HUMAN Ubiquinol-cytochrome c reductase complex 0.009

core protein 2

UNKNOWN

CATB CHICK Cathepsin B precursor (EC 3.4.22.1)

0.009

ACTT_FUGRU Actin $\quad 0.01$

UNKNOWN $\quad 0.01$

PUM1 MOUSE Pumilio homolog $1 \quad 0.01$

LCB1_HUMAN Serine palmitoyltransferase 1 (EC 2.3.1.50) $\quad 0.01$

* Where $P<0.01$ by $t$ test (TIGR Multiple Experiment Viewer software; The Institute for Genomic Research, J. Craig Venter Institute, Rockville, MD, USA). The fifty-five genes are classified following the $P$ values.

† http://public-contigbrowser.sigenae.org:9090/index.html 
Table 9. Hepatic transcripts exhibiting higher abundance in fish fed with vegetable proteins after microarray analysis*

\begin{tabular}{|c|c|c|c|}
\hline Clone name & Sigenae contig $\dagger$ & Swissprot-hit description & $P$ \\
\hline tcay0001b.g.18 & AF281350.1.om.4 & UNKNOWN & 0.001 \\
\hline 1RT120N05_B_G03 & 15062971.1.om.4 & DTD_HUMAN Sulfate transporter & 0.002 \\
\hline tcbk0031c.h. 14 & 15015934.1.om.4 & BRD2_HUMAN Bromodomain-containing protein 2 & 0.002 \\
\hline 1RT120C23_A_B12 & 15062875.1.om.4 & YQIK_BACSU Hypothetical protein yqiK & 0.002 \\
\hline tcba0020c.0.23 & tcba0020c.0.23_5.1.om.4 & UNKNOWN & 0.003 \\
\hline tcbk0052c.c.07 & tcbk0052c.c.07_5.1.om.4 & SMF1_HUMAN SWI/SNF-related & 0.004 \\
\hline 1RT151D10_D_B05 & tcay0015b.p.08_3.1.om.4 & PTPA_RABIT Protein phosphatase 2A & 0.007 \\
\hline 1RT90J08_D_E04 & 15016677.1.om.4 & RBB5_HUMAN Retinoblastoma-binding protein 5 & 0.007 \\
\hline 1RT42N11_B_G06 & 15079057.1.om.4 & AGM1_HUMAN Phosphoacetylglucosamine mutase (EC 5.4.2.3) & 0.009 \\
\hline 1RT162N09_B_G05 & 15083591.1.om.4 & LAT2_RAT Large neutral amino acids transporter small subunit 2 & 0.009 \\
\hline 1RT35I10_C_EO5 & 15077084.1.om.4 & DYN1_HUMAN Dynamin-1 (EC 3.6.5.5) & 0.009 \\
\hline tcba0023c.h.11 & tcba0023c.h.11_5.1.om.4 & UNKNOWN & 0.009 \\
\hline tcbk0016c.a.07 & tcbk0016c.a.07_5.1.om.4 & ACTM_APLCA Actin & 0.009 \\
\hline tcbk0021c.h.05 & tcbk0021c.h.05_5.1.om.4 & KELC_DROME Ring canal kelch protein & 0.009 \\
\hline tcac0003c.h.09 & tcac0003c.h.09_3.1.om.4 & PAB5_ARATH Polyadenylate-binding protein 5 & 0.009 \\
\hline
\end{tabular}

*Where $P<0.01$ by $t$ test (TIGR Multiple Experiment Viewer software; The Institute for Genomic Research, J. Craig Venter Institute, Rockville, MD, USA). The fifteen genes are classified following the $P$ values.

† http://public-contigbrowser.sigenae.org:9090/index.html

Gene profiling after fish oil replacement by vegetable oil mixture: focus on specific genes

We found that replacement of fish oil by vegetable oils has a major impact on lipid, energy and xenobiotic metabolism.

As regards key actors involved in intermediary metabolism, we analysed FAS, which is the key enzyme of fatty acid biosynthesis in vivo; this metabolic pathway is highly active in rainbow trout liver ${ }^{(32)}$. Two FAS cDNA were spotted on the microarrays and both of them were detected (and clustered) to be down-regulated in the fish fed with vegetable oils and confirmed by quantitative RT-PCR. FAS gene expression was 10 -fold lower in the fish fed with vegetable oils. The lower level of hepatic FAS gene expression in the trout fed with vegetable oils could be explained by the diets based on vegetable oils having higher levels of linoleic $(18: 2 n-6)$ and linolenic $(18: 3 n-3)$ acids than the fish oil ${ }^{(18)}$ and by linolenic acid known to decrease FAS mRNA levels ${ }^{(33)}$. The unambiguous finding in the present study of a significantly lower (10-fold) FAS gene expression in the fish fed with vegetable oils was not linked with a decrease of liver FAS activity in the same fish. This was even though FAS activity (IU/g liver) tended to be lower $(P=0.051)$ for the fish fed vegetable oils (4.0 (SD 0.9)) compared with fish fed fish oil (6.1 (SD 1.8)) (see Richard et al. ${ }^{(18)}$ ). It cannot also explain the modification of whole-body fatty acid composition which reflected mainly the composition of the diets (Tables 1 and 5). Our data about FAS mRNA levels suggest once more that molecular data (measures of gene expression level) are not always associated with significant effects at the protein-metabolic pathway level.

The second actor is one involved in lysosomal proteolysis, which includes proteases such as cathepsin $\mathrm{B}^{(34)}$. Cell proteins are always in a dynamic equilibrium between synthesis and degradation depending on nutritional status ${ }^{(35)}$. Lower expression of the CATB gene in the trout fed with vegetable oils cannot be presently explained and it is difficult to provide any putative biological consequence of this observation. The third gene is the ubiquinol cytochrome c reductase (UCR) which is involved in mitochondrial metabolism, i.e. oxidative phosphorylation. We found that the expression of UCR was down-regulated in the fish fed with vegetable oils. This is in agreement with the data of Barzanti et al. ${ }^{(36)}$ in rats, which showed a putative modification of UCR gene expression by dietary lipids.

Part of our analysis in the fish fed with vegetable oils dealt with the hepatic detoxification metabolism which is catalysed by a multi-enzyme family, namely the cytochromes P450s in rainbow trout ${ }^{(37)}$. These enzymes have generally a large spectrum of endogenous as well as exogenous substrates, and CYP1A members catalyse the biotransformation of environmental disruptors or pollutants such as polychlorinated biphenyls in the liver before their elimination. Because CYP1A genes are induced by the presence of their substrates ${ }^{(37)}$, the lower expression of the CYP1A3 gene in the liver of the trout fed diets with vegetable oils could be due to the lower levels of pollutants such as dioxins in these diets. This result is not surprising given that the fish oil is susceptible to contamination with lipophilic organic chemicals that are now ubiquitous in the marine ecosystems and consequently in aquaculture systems $^{(38,39)}$. Our own results (G Corraze, unpublished results) show that the muscle levels of dioxins and polychlorinated biphenyls are reduced in trout fed vegetable oils compared with those fed fish oils (WHO toxic equivalent: $1.96 \mathrm{pg} / \mathrm{g}$ and $1.08 \mathrm{pg} / \mathrm{g}$ for fish oil and vegetable oil groups, respectively). The CYP3A27 in rainbow trout which metabolises testosterone can be reduced by phyto-oestrogen; however, this cannot presently easily explain the higher CYP3A27 gene expression in the fish fed vegetable oils. Moreover, CYP3A27 also has some similarities with the human CYP3A4 ${ }^{(40)}$ which can convert cholesterol to $4-\beta$-hydroxycholestrol before its elimination in bile salts ${ }^{(41)}$. Thus, the higher expression of the CYP3A27 gene in the rainbow trout fed with vegetable oils can be related to the lower level of plasma cholesterol observed in these fish (6.45 (SD 1.07) v. 3.97 (SD 0.23) g/l for fish fed fish oil and vegetable oils respectively; see Richard et al. ${ }^{(18)}$ ), suggesting that higher CYP3A27 activities can be the cause of the lower level of cholesterol in plasma. This needs further study to confirm and understand the link between fish oil replacement and the higher level of the CYP3A27 gene. Overall, the two hepatic 
Table 10. Hepatic transcripts exhibiting lower abundance in fish fed with vegetable proteins after microarray analysis*

\begin{tabular}{|c|c|c|c|}
\hline Clone name & Sigenae contig† & Swissprot-hit description & $P$ \\
\hline tcba0020c.j.10 & tcav0004c.f.03_5.1.om.4 & MTL2_MOUSE Methyltransferase-like protein 2 (EC 2.1.1.-) & $9.7 \times 10^{-4}$ \\
\hline tcad0009a.k.02 & tcad0009a.k.02_3.1.om.4 & CRB1_CHICK Beta crystallin B1 & $3.2 \times 10^{-4}$ \\
\hline tcay0021b.b.07 & tcay0021b.b.07_3.1.om.4 & CPM1_ONCMY Cytochrome P450 2M1 (EC 1.14.14.1) & $3.4 \times 10^{-4}$ \\
\hline tcay0011b.k.04 & tcay0011b.k.04_5.1.om.4 & CAO3_HUMAN Acyl-coenzyme A oxidase 3 & $3.4 \times 10^{-4}$ \\
\hline tcbi0009d.I.22 & tcbi0009d.I.22_5.1.om.4 & RL13_BRARE 60S ribosomal protein L13 & 0.001 \\
\hline tcay0023b.k.09 & tcay0023b.k.09_3.1.om.4 & $\begin{array}{l}\text { MEPD_PIG Thimet oligopeptidase (EC 3.4.24.15) } \\
\text { (Endopeptidase 24.15) }\end{array}$ & 0.001 \\
\hline 1RT148H10_D_D05 & tcay0038b.p.14_5.1.om.4 & $\begin{array}{l}\text { SN24_HUMAN Possible global transcription } \\
\text { activator SNF2L4 }\end{array}$ & 0.001 \\
\hline tcbk0002c.e.02 & 15012882.1.om.4 & RL35_HUMAN 60S ribosomal protein L35 & 0.002 \\
\hline tcad0004a.f.19 & tcad0004a.f.19_3.1.om.4 & NIFU_RICPR NifU-like protein & 0.002 \\
\hline 1RT165A11_A_A06 & tcaj0001a.a.12_5.1.om.4 & $\begin{array}{l}\text { U520_HUMAN U5 small nuclear ribonucleo } \\
\text { protein } 200 \mathrm{kDa} \text { helicase ( } E C \text { 3.6.1.-) }\end{array}$ & 0.002 \\
\hline tcba0008c.m.21 & tcay0022b.h.16_3.1.om.4 & SEP8_HUMAN Septin 8 & 0.003 \\
\hline tcac0003c.f.09 & 15077731.1.om.4 & SFR2_MOUSE Splicing factor & 0.003 \\
\hline tcba0011c.d.17 & tcba0011c.d.17_5.1.om.4 & $\begin{array}{l}\text { KAP2_BOVIN cAMP-dependent protein kinase } \\
\text { type II-alpha regulatory chain }\end{array}$ & 0.003 \\
\hline tcac0002c.a.04 & AF390023.1.om.4 & GLNA_SQUAC Glutamine synthetase & 0.003 \\
\hline tcba0018c.b.23 & tcay0014b.h.22_3.1.om.4 & $\begin{array}{l}\text { UCR1_MOUSE Ubiquinol-cytochrome c reductase } \\
\text { complex core protein I }\end{array}$ & 0.003 \\
\hline tcab0002c.l.09 & tcab0002c.l.09_5.1.om.4 & RL27_HUMAN 60S ribosomal protein L27 & 0.004 \\
\hline tcbk0020c.f.18 & tcay0014b.i.10_3.1.om.4 & CN7B_SCHPO COP9/signalosome complex subunit 7B & 0.004 \\
\hline tcal0001a.0.19 & 15029915.1.om.4 & CCR4_RAT C-X-C chemokine receptor type 4 & 0.004 \\
\hline tcbk0058c.g.14 & 15060181.1.om.4 & CWFF_SCHPO Cell cycle control protein cwf15 & 0.004 \\
\hline tcba0006c.l.19 & tcay0018b.i.17_5.1.om.4 & TFR1_CRIGR Transferrin receptor protein 1 & 0.004 \\
\hline tcbk0044c.l.01 & 15025792.1.om.4 & RLA2_BRAFL 605 acidic ribosomal protein $\mathrm{P} 2$ & 0.005 \\
\hline tcab0002c.e.12 & tcab0002c.e.12_5.1.om.4 & $\begin{array}{l}\text { YFW7_SCHPO Hypothetical protein PB2B4.07 } \\
\text { in chromosome I }\end{array}$ & 0.005 \\
\hline tcbk0051c.f.12 & tcbk0005c.0.13_5.1.om.4 & RS16_HUMAN 40S ribosomal protein S16 & 0.005 \\
\hline 1RT119C21_A_B11 & tcad0001a.m.03_3.1.om.4 & CIA1_HUMAN WD-repeat containing protein Ciao 1 & 0.005 \\
\hline tcaa0002c.f.02 & tcaa0002c.f.02_5.1.om.4 & VATB_CHICK Vacuolar ATP synthase subunit B (EC 3.6.3.14) & 0.005 \\
\hline tcay0012b.b.15 & tcay0030b.e.18_3.1.om.4 & CWFO_SCHPO Cell cycle control protein cwf24 & 0.005 \\
\hline tcam0002b.e.05 & tcad0009a.e.24_3.1.om.4 & SPRC_RAT SPARC precursor & 0.005 \\
\hline tcad0008a.p.16 & tcad0003a.i.20_5.1.om.4 & $\begin{array}{l}\text { IUNH_CRIFA Inosine-uridine preferring nucleoside } \\
\text { hydrolase (EC 3.2.2.1) }\end{array}$ & 0.005 \\
\hline tcbk0018c.n.07 & tcay0017b.j.17_3.1.om.4 & ACPM_MOUSE Acyl carrier protein & 0.005 \\
\hline tcba0009c.f.23 & tcba0009c.f.23_5.1.om.4 & ABC1_HUMAN ATP-binding cassette & 0.006 \\
\hline tcay0013b.g.06 & 15068153.1.om.4 & $\begin{array}{l}\text { SGTB_HUMAN Small glutamine-rich tetratricopeptide } \\
\text { repeat-containing protein B }\end{array}$ & 0.006 \\
\hline tcay0031b.j.13 & tcay0018b.I.03_3.1.om.4 & TPM4_HORSE Tropomyosin alpha 4 chain & 0.006 \\
\hline tcay0008b.h.15 & 15073662.1.om.4 & ARGI_HUMAN Arginase $1(E C$ 3.5.3.1) & 0.006 \\
\hline tcbk0053c.i.13 & tcba0028c.p.14_5.1.om.4 & INPP_MOUSE Inositol polyphosphate 1-phosphatase (EC 3.1.3.57) & 0.006 \\
\hline tcad0002a.k.18 & tcad0002a.k.18_5.1.om.4 & RGS5_MOUSE Regulator of G-protein signaling 5 (RGS5) & 0.006 \\
\hline tcbk0002c.l.10 & tcay0025b.0.12_3.1.om.4 & PSB7_RAT Proteasome subunit beta type 7 precursor (EC 3.4.25.1) & 0.006 \\
\hline tcbk0036c.m.09 & tcay0016b.p.23_3.1.om.4 & M2OM_MOUSE Mitochondrial 2-oxoglutarate/malate carrier protein (OGCP) & 0.006 \\
\hline tcbk0018c.b.15 & 15019342.1.om.4 & SHP_MOUSE Orphan nuclear receptor SHP & 0.007 \\
\hline tcay0028b.g.04 & tcay0028b.g.04_3.1.om.4 & IF2A_RAT Eukaryotic translation initiation factor 2 subunit 1 (elF-2-alpha) & 0.007 \\
\hline tcay0003b.g.15 & 15073721.1.om.4 & QOR_HUMAN Quinone oxidoreductase $(E C$ 1.6.5.5) & 0.007 \\
\hline tcay0020b.j.18 & tcay0020b.j.18_3.1.om.4 & ICMT_XENLA Protein-S isoprenylcysteine O-methyltransferase (EC 2.1.1.100) & 0.007 \\
\hline tcbk0024c.f.12 & 17239246.2.om.4 & RL28_MOUSE 60S ribosomal protein L28 & 0.008 \\
\hline tcac0001c.i.22 & tcac0001c.i.22_3.1.om.4 & UNKNOWN & 0.008 \\
\hline tcac0006c.n.11 & 15064666.1.om.4 & DIM1_HUMAN Spliceosomal U5 snRNP-specific $15 \mathrm{kDa}$ protein & 0.008 \\
\hline tcbk0005c.c. 21 & tcbk0005c.c.21_5.1.om.4 & CT20_HUMAN Protein C20orf20 & 0.008 \\
\hline tcbk0033c.0.02 & tcbk0033c.0.02_5.1.om.4 & $\begin{array}{l}\text { PRTP_HUMAN Lysosomal protective protein precursor } \\
(E C \text { 3.4.16.5) (Cathepsin A) }\end{array}$ & 0.008 \\
\hline 1RT102K01_A_F01 & 15017476.1.om.4 & UNKNOWN & 0.008 \\
\hline tcav0003c.h.07 & tcav0003c.h.07_3.1.om.4 & ARH7_HUMAN Rho guanine nucleotide exchange factor 7 & 0.008 \\
\hline tcba0001c.m.17 & tcba0001c.m.17_5.1.om.4 & KBTA_RAT Kelch repeat and BTB domain containing protein 10 & 0.009 \\
\hline tcac0006c.p.12 & AF115536.1.om.4 & TAP1_HUMAN Antigen peptide transporter 1 (APT1) & 0.009 \\
\hline tcbk0022c.f.06 & tcay0028b.c.20_3.1.om.4 & $\begin{array}{l}\text { P44_PANTR Non-A non-B hepatitis-associated } \\
\text { microtubular aggregates protein (Antigen p44) }\end{array}$ & 0.009 \\
\hline tcad0006a.e.03 & tcad0002a.0.04_3.1.om.4 & ARLL_HUMAN ADP-ribosylation factor-like protein 4L & 0.009 \\
\hline tcba0002c.p.17 & $17244760.2 .0 m .4$ & COXO_MOUSE Cytochrome c oxidase polypeptide VIIc & 0.009 \\
\hline tcay0001b.i.04 & tcay0016b.j.19_3.1.om.4 & AR34_HUMAN ARP2/3 complex $34 \mathrm{kDa}$ subunit (P34-ARC) & 0.009 \\
\hline tcad0005a.c.22 & tcad0005a.c.22_5.1.om.4 & AATM_RAT Aspartate aminotransferase & 0.009 \\
\hline tcbk0050c.m.05 & tcay0018b.g.16_3.1.om.4 & ASAH_HUMAN Acid ceramidase precursor (EC 3.5.1.23) & 0.01 \\
\hline tcad0006a.d.14 & tcad0006a.d.14_3.1.om.4 & CB45_RAT $45 \mathrm{kDa}$ calcium-binding protein precursor & 0.01 \\
\hline tcbk0057c.p.24 & tcay0027b.m.18_3.1.om.4 & TAM2_HUMAN Translocation associated membrane protein 2 & 0.01 \\
\hline tcac0003c.k.15 & 15014990.1.om.4 & PSA1_HUMAN Proteasome subunit alpha type 1 (EC 3.4.25.1) & 0.01 \\
\hline tcay0039b.h.02 & tcay0033b.m.11_5.1.om.4 & RL2_GEOSL 50 S ribosomal protein L2 & 0.01 \\
\hline
\end{tabular}

* Where $P<0.01$ by $t$ test (TIGR Multiple Experiment Viewer software; The Institute for Genomic Research, J. Craig Venter Institute, Rockville, MD, USA). The sixty genes are classified following the $P$ values.

† http://public-contigbrowser.sigenae.org:9090/index.html 
(a)

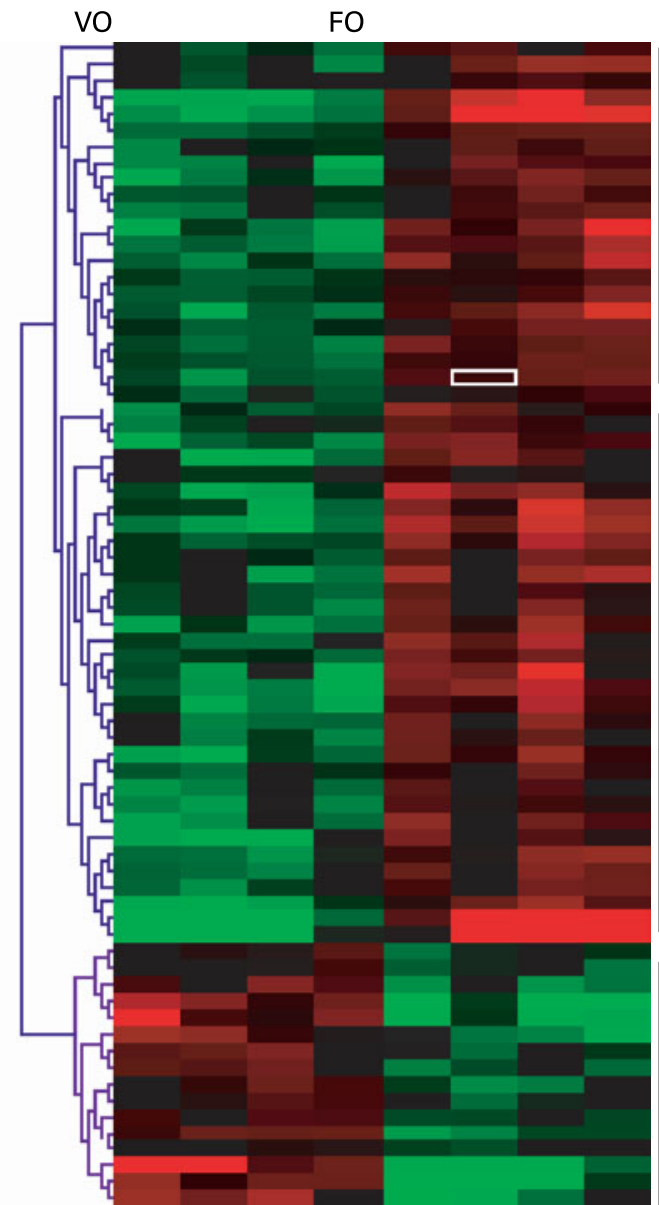

(b)

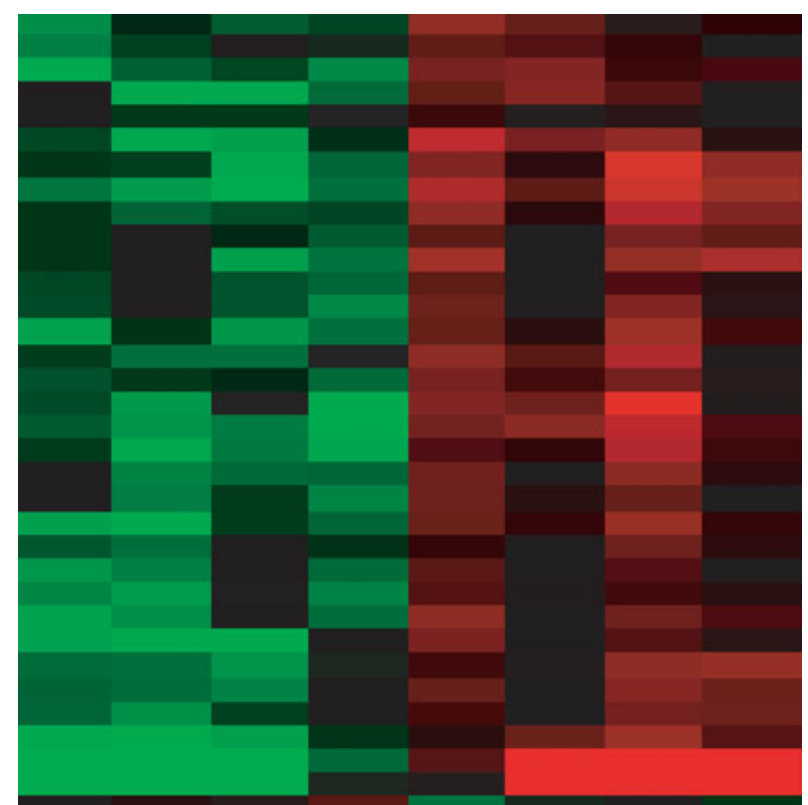

Cluster I

(n 22 genes)

Cluster II

(n 33 genes)

Cluster III

(n 16 genes)

Cathepsin B (CATB)

Serine/threonine protein kinase Sgk3 (SGK3)

Pre-mRNA processing protein PRP39 (PR39)

UMP-CMP kinase (KCY)

Unknown

Egl nine homolog 1 (EGL1)

Unknown

Unknown

Leucin rich protein SHOC2 (SHO2)

Transmembrane 9 superfamily protein member 3 precursor (T9S3)

Serine/threonine protein kinase Nek1 (NEK1)

Glycine dehydrogenase (GCSP)

Heat and acid stable phosphoprotein (HP28)

Basement membrane specific heparin sulfate proteoglycan core protein precursor (PGBM)

Transcription repressor NF-X1 (NFX1)

Pumilio homolog 1 (PUM1)

Ubiquinol-cytochrome c reductase complexe core protein 2 (UCR2)

GTP-binding protein SAR1a (SARA)

Asparaginyl-tRNA synthetase (SYN)

Unknown

$47 \mathrm{kDa}$ Heat shock protein precursor (HS47)

Transitional endoplasmic reticulum ATPase (TERA)

Annexin A13 (ANXD)

Ubiquitin protein ligase pub1 (PUB1)

Unknown

Pre-mRNA splicing factor RNA helicase (DD15)

Long-chain fatty acid-CoA ligase 4 (LCF4)

Acetyl-coenzyme A synthetase (ACS1)

Transcription factor MafK (MAFK)

Pyridoxin $5^{\prime}$-phosphate oxidase (PNPO)

Fatty acid synthase (FAS)

Fatty acid synthase (FAS)

Fig. 1. (a) Hierarchical classification of differentially expressed genes between fish fed with or without fish oil (FO) $(P<0.01, t$ test, TIGR Multiple Experiment Viewer software; The Institute for Genomic Research, J. Craig Venter Institute, Rockville, MD, USA). Seventy-one hepatic genes were differentially expressed between the two dietary groups: sixteen were over-expressed (in red) and fifty-five were under-expressed (in green) in fish fed with vegetable oils (VO). (b) Detailed description of cluster II. 
(a)

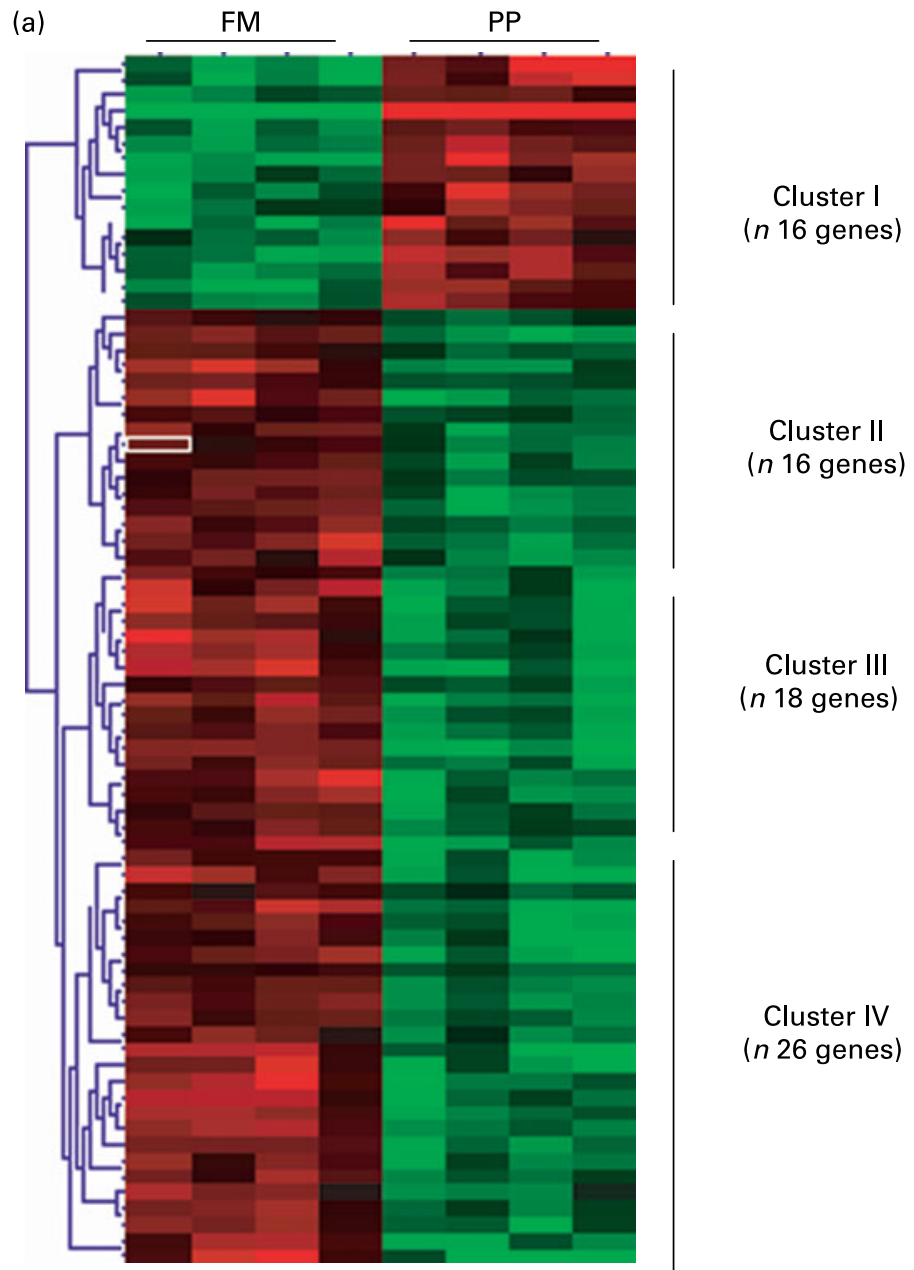

(n 16 genes)

Cluster III

(n 18 genes)

Cluster IV

(n 26 genes)

(b)

FM

PP

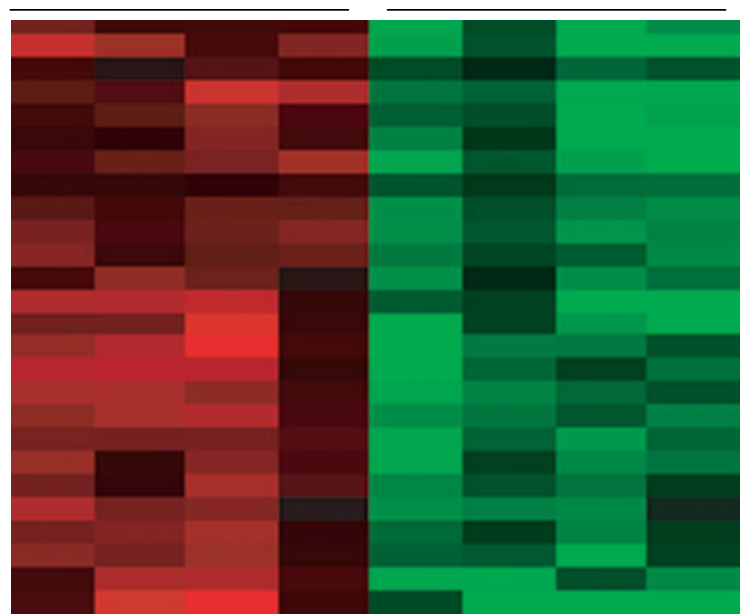

Translation initiation factor 2 subunit 2 (IF2A) Transferrin receptor protein 1 (TFR1) Septin 8 (SEP8)

Cell cycle control protein (CWFF)

Signalosome complex subunit 7B (CN7B)

Proteasome subunit alpha type 1 (PSB7)

5 (RGS5)

Mitochondrial 2-oxoglutarate/malate carrier protein (M2OM)

Cytochrome P450 2M1 (CPM1)

Acyl-coenzyme A oxidase 3 (CAO3)

Global transcripton activator SNF2L4 (SN24)

Aspartate amino transferase (AATM)

Aspartate

Unknown

$60 S$ acidic ribosomal protein P2 (RLA2)

$60 S$ ribosomal protein L35 (RL35)

Inositol polyphosphate 1-phosphatase (INPP)

60 sibosomal protein L13 (RL13)

Unknown

$50 S$ ribosomal protein $\mathrm{L} 2$ (RL2)

Unknown

Spliceosomal U5 snRNP-specific $15 \mathrm{kDa}$ protein (DIM1)

Protein S-isoprenylcysteine O-methyltransferase (ICMT)

40 S ribosomal protein S16 (RS16)

Rho guanine nucleotide exchange factor 7 (ARH7)

Fig. 2. (a) Hierarchical classification of differentially expressed genes between fish fed with or without fishmeal (FM) ( $P<0.01, t$ test, TIGR Multiple Experiment Viewer software; The Institute for Genomic Research, J. Craig Venter Institute, Rockville, MD, USA). Seventy-five hepatic genes were differentially expressed between the two dietary groups: fifteen were over-expressed (in red) and sixty were under-expressed (in green) in fish fed with plant proteins (PP). (b) Detailed description of cluster IV. 
Table 11. Major functional groups of hepatic transcripts exhibiting lower abundance in fish fed with vegetable oils after gene ontology analysis (GoMiner)*

\begin{tabular}{|c|c|c|}
\hline Biological process & Function & best_swissprot_hit_accession number \\
\hline \multirow[t]{6}{*}{ Lipid metabolism } & Fatty acid biosynthesis & FAS_CHICK \\
\hline & Fatty acid biosynthesis & FAS_ANSAN \\
\hline & Fatty acid metabolism & LCF4_RAT \\
\hline & Sphingolipid metabolism & LCB1_HUMAN \\
\hline & Fatty acid, steroid and xenobiotic oxidation & CP13_ONCMY \\
\hline & Lipid biosynthesis (isoprenoid biosynthesis) & ACS1_RHIME \\
\hline \multirow[t]{8}{*}{ Protein catabolism } & Protein metabolism & EGL1_HUMAN \\
\hline & Protein repair & YCD1_HUMAN \\
\hline & Proteolysis & CATD_CLUHA \\
\hline & Proteolysis & UCR2_HUMAN \\
\hline & Proteolysis & CATB_CHICK \\
\hline & Proteolysis (ubiquitin mediated) & PUB1_SCHPO \\
\hline & Protein catabolism & PRSX_HUMAN \\
\hline & Amino acid metabolism (glycine, serine and threonine metabolism) & GCSP_MOUSE \\
\hline \multirow[t]{4}{*}{ Protein modification } & Protein amino acid phosphorylation; mitosis & NEK1_HUMAN \\
\hline & Protein amino acid phosphorylation & SGK3_HUMAN \\
\hline & Protein biosynthesis & SYQ_HUMAN \\
\hline & Protein folding & TCPB_HUMAN \\
\hline \multirow[t]{4}{*}{ Transcription regulation } & Aminoacyl-tRNA biosynthesis & SYN_HUMAN \\
\hline & mRNA splicing & SMD2_HUMAN \\
\hline & mRNA splicing & PR39_YEAST \\
\hline & mRNA splicing & DD15_MOUSE \\
\hline
\end{tabular}

* GoMiner software (Genomics and Bioinformatics Group, National Institutes of Health, Bethesda, MD, USA; http://discover.nci.nih.gov/gominer/).

cytochrome P450s described here can be proposed as molecular markers of dietary fish oil replacement by vegetable oils even though measures of enzymic activities will be necessary to confirm this status.

Gene profiling after fishmeal replacement by plant proteins: focus on specific genes

As the trout fed with plant proteins had significantly lower growth than the fish fed fishmeal, it was worth searching potential molecular actors to explain this phenotype, such as ribosomal proteins and glutamine synthetase.

A relatively high number of genes $(n 8)$ coding for ribosomal proteins were detected in microarrays to be down-regulated in these fish. Moreover, we could classify them in the same cluster (IV) and considered that this set to be related to the lower growth of fish (for example, lower protein synthesis). Unfortunately, it was not possible to confirm these data by quantitative RT-PCR. We have no explanation to understand the discrepancy between the microarray and quantitative RT-PCR data. It is possible that these genes are false positive even though the data of microarrays seem unequivocal in humans (eight ribosomal genes with differential expression). An another explanation may be found in the specificity of the ribosomal genes: (i) there are more than seventy-nine ribosomal genes and, in trout, these are potentially in higher number due to pseudotetraploidy of the salmonids linked to a recent duplication of the genome ${ }^{(42,43)}$ and (ii) all these genes are not under the same control of their expression $^{(44)}$. Thus, it is possible that we have not analysed the most appropriate ribosomal protein genes by quantitative RT-PCR. Overall, we prefer to take these data about ribosomal proteins with caution even though the growth rate and feed efficiency (which are major endpoints of the present nutritional experiments linked to the proteosynthesis potential) were unambiguously lower in the fish fed plant proteins than the fish fed fishmeal $(P<0 \cdot 01)$.

We found that the glutamine synthetase mRNA levels were lower in the fish fed with plant proteins. Indeed, the lower glutamine synthetase gene expression (8-fold) observed in microarrays seems to be due to the lower levels of the two isoforms of the glutamine synthetase, i.e. GS01 (7-fold) and GS03 (6.9-fold), two genes highly correlated with rising levels of ammonia in rainbow trout ${ }^{(45)}$. Glutamine synthetase catalyses the transformation of glutamic acid into glutamine, leading to the elimination of ammonia $^{(46)}$. Rainbow trout do have an active ammonia detoxification system, and glutamine synthetase activity increases after a meal naturally rich in proteins ${ }^{(47)}$ not only in the brain but also in the liver ${ }^{(45)}$. In the present study, the fishmeal replacement by plant proteins was associated with lower hepatic glutamine synthetase gene expression, thus potentially lowering the capacity of ammonia detoxification, possibly explaining the lower growth of these fish. However, the link between fishmeal replacement by plant proteins (naturally rich in glutamate) and lower glutamine synthetase gene expression is not clear and needs further study, especially at the level of enzyme activities.

\section{Comparison with others nutrigenomic studies in fish}

Very few studies have used nutrigenomics as a tool for the analysis of dietary fatty acids-gene interactions in aquaculture nutrition. Jordal et al. ${ }^{(48)}$ found regulation of several individual genes (for example, $\Delta 6$-desaturase, peroxysome proliferator-activated receptor, mitochondrial genes) after replacement of fish oil by $75 \%$ rapeseed oil in Atlantic salmon. We do not find any common differentially expressed genes between the two studies. Indeed, we do not observe any change in $\Delta 6$-desaturase gene expression following the microarray analysis (data not shown) in contrast to Jordal et al. ${ }^{(48)}$, suggesting that the effects on gene profiling by vegetable oil replacement 
Table 12. Major functional groups of hepatic transcripts exhibiting lower abundance in fish fed with vegetable proteins after gene ontology analysis $(\text { GoMiner) })^{*}$

\begin{tabular}{|c|c|c|}
\hline Biological process & Function & best_swissprot_hit_accession numbe \\
\hline \multirow[t]{4}{*}{ Lipid metabolism } & Fatty acid biosynthesis; oxidative phosphorylation & ACPM_MOUSE \\
\hline & Fatty acid metabolism (sphingolipid metabolism) & ASAH_HUMAN \\
\hline & Fatty acid oxidation & CAO3_HUMAN \\
\hline & Cholesterol metabolism & ABC1_HUMAN \\
\hline \multirow[t]{4}{*}{ Amino acid metabolism } & Amino acid catabolism & AATM_RAT \\
\hline & Amino acid metabolism & GLNA_SQUAC \\
\hline & Amino acid metabolism & MTL2_MOUSE \\
\hline & Amino acid metabolism & ARGI_HUMAN \\
\hline \multirow[t]{10}{*}{ Protein biosynthesis } & Ribosome assembly & RLA2_BRAFL \\
\hline & Ribosome assembly & RL27_HUMAN \\
\hline & Ribosome assembly & CB45_RAT \\
\hline & Ribosome assembly & RL28_MOUSE \\
\hline & Ribosome assembly & RL35_HUMAN \\
\hline & Ribosome assembly & RL13_BRARE \\
\hline & Ribosome assembly & RL2_GEOSL \\
\hline & Ribosome assembly & RS16_HUMAN \\
\hline & Protein biosynthesis & PAB5_ARATH \\
\hline & Translation initiation & IF2A_RAT \\
\hline \multirow[t]{3}{*}{ Protein transport } & Intracellular protein transport & TAM2_HUMAN \\
\hline & Intracellular protein transport & PRTP_HUMAN \\
\hline & Intracellular protein transport & ICMT_XENLA \\
\hline \multirow[t]{7}{*}{ Transcription regulation } & mRNA splicing & DIM1_HUMAN \\
\hline & mRNA splicing & CWFO_SCHPO \\
\hline & mRNA splicing & CWFF_SCHPO \\
\hline & mRNA splicing & U520_HUMAN \\
\hline & mRNA splicing & SFR2_MOUSE \\
\hline & Transcription regulation & CT20_HUMAN \\
\hline & Transcription regulation & SN24_HUMAN \\
\hline \multirow{8}{*}{$\begin{array}{l}\text { Generation of metabolite } \\
\text { precursors and energy }\end{array}$} & ATP biosynthesis & VATB_CHICK \\
\hline & Oxidative phosphorylation (electron transport) & CPM1_ONCMY \\
\hline & Oxidative phosphorylation (electron transport) & UCR1_MOUSE \\
\hline & Oxidative phosphorylation, electron transport & COXO_MOUSE \\
\hline & Protein catabolism (proteasome) & PSB7_RAT \\
\hline & Protein catabolism (proteasome) & PSA1_HUMAN \\
\hline & Purine salvage & IUNH_CRIFA \\
\hline & Repair iron-sulfur proteins & NIFU_RICPR \\
\hline \multirow[t]{4}{*}{ Signal transduction } & Signal transduction & KAP2_BOVIN \\
\hline & Signal transduction & INPP_MOUSE \\
\hline & Signal transduction & RGS5_MOUSE \\
\hline & Signal transduction & ARLL_HUMAN \\
\hline
\end{tabular}

* GoMiner software (Genomics and Bioinformatics Group, National Institutes of Health, Bethesda, MD, USA; http://discover.nci.nih.gov/gominer/).

in fish may possibly vary with vegetable oil source and/or with fish species.

Concerning the analysis of dietary protein-gene interaction at the integrative level, an earlier study analysed the effect of dietary plant-protein substitution on hepatic metabolism using a proteomic approach ${ }^{(14)}$. The majority of the up-regulated proteins affected by the plant-protein diets were involved in energy production (NADPH, electron transferring flavoproteins). This is in contrast to data from the present study, in which lower expression levels of genes involved in energy

Table 13. Selected genes analysed by real-time PCR: effect of dietary fish oil (FO) replacement by vegetable oils (VO)

\begin{tabular}{lccrr}
\hline Gene & Fold-regulation (in VO fish) $\dagger$ & $P$ & CV (\%) FO & CV (\%) VO \\
\hline Fatty acid synthase & -10.1 & $<0.02$ & 2.5 & 18.4 \\
Ubiquinol-cytochrome c reductase & -3.1 & 0.001 & 1.1 & 1.3 \\
Cathepsin B & -2.3 & $<0.05$ & 1.7 & 1.1 \\
CYP1A (3A/A1) & -2.7 & $<0.02$ & 4.2 & 2.5 \\
CYP3A (A27) & +2.7 & $<0.005$ & 2.9 & 2.3 \\
\hline
\end{tabular}

* Statistical differences in gene expression were evaluated between group means (six samples per group) by randomisation tests using the Relative Expression Software tool (REST $\mathbb{C})^{(23)}$. The transcript level of target genes was normalised with EF1 $\alpha-$ expressed transcripts.

$\dagger$ Positive and negative regulation means that the target gene is expressed at a higher or lower level, respectively. 
Table 14. Selected genes analysed by real-time PCR: effect of dietary fishmeal (FM) replacement by plant proteins $(\mathrm{PP})^{\star}$

\begin{tabular}{lcccc}
\hline Gene & Fold-regulation (in PP fish)† & $P$ & CV (\%) FM & CV (\%) PP \\
\hline Glutamine synthetase & -8.0 & 0.001 & 0.5 & 0.2 \\
Glutamine synthetase GS03 & -7.1 & 0.007 & 1.22 & 9.06 \\
Glutamine synthetase GS02 & +2.1 & 0.26 & 11.73 & 13.03 \\
Glutamine synthetase GS01 & -6.9 & $<0.02$ & 3.85 & 5.14 \\
Ribosomal protein L35 & +1.4 & 0.42 & 1.9 & 4.4 \\
Ribosomal protein L27 & -1.1 & 0.48 & 1.0 & 1.0 \\
Ribosomal protein S6 & -1.4 & 0.08 & 0.2 & 0.9 \\
Ribosomal protein S7 & +1.4 & 0.08 & 1.0 & 1.6 \\
\hline
\end{tabular}

* Statistical differences in gene expression were evaluated between group means (six samples per group) by randomisation tests using the Relative Expression Software tool (RESTCC) ${ }^{(23)}$. The transcript level of target genes was normalised with EF1 $\alpha$-expressed transcripts.

$\dagger$ Positive and negative regulation means that the target gene is expressed at a higher or lower level, respectively.

metabolism were found. However, we should recognise that comparison between transcriptomic and proteomic data is difficult. A recent study by Salem et al. ${ }^{(49)}$ on the hepatic gene expression profiles between fasted and fed rainbow trout showed an inhibition of protein synthesis gene expression (ribosomal protein) in fasted fish; these data can be related to ours on trout fed with plant-protein diets having reduced growth.

\section{Conclusion}

Our data based on a transcriptomic approach and confirmed by quantitative RT-PCR enable us to identify modifications of hepatic gene expression after intake of a plant-based diet by rainbow trout. This non-exhaustive list of genes could be useful and used in the future as powerful tools to more closely monitor the effects of the evolution of feeds used for farmed fish ${ }^{(50)}$.

\section{Acknowledgements}

We acknowledge M. J. Borthaire and C. Nunez for their excellent technical assistance. We thank F. Terrier, Y. Hontang and F. Sandres for rearing fish in the INRA experimental farm (Donzacq, Landes, France).

The present study was financed by the AGENAE French programme (Analyse du GENome des Animaux d'Elevage), CIPA (Comité Interprofessionnel des Produits de l'Aquaculture), OFIMER (Office National Interprofessionnel des Produits de la Mer et de l'Aquaculture), Aquitaine Region (no. CCRRDT-20051303004AB), 5th European projects (FAIR no. QLK5-2000-30068, 'Perspectives of Plant Protein use in Aquaculture' (PEPPA) and FAIR no. Q5RS-200030058, 'Researching Alternatives to Fish Oils in Aquaculture' (RAFOA)) and a 6th PCRD European project (contract no. 016249-2, 'Sustainable Aquafeeds to Maximise the Health Benefits of Farmed Fish for Consumers' (AQUAMAX)).

F. P. and D. E. were responsible for generating the trout microarrays. C. K. was co-responsible for generating statistical analysis of the microarray data. E. P.-J. generated the quantitative RT-PCR data. N. R., G. C., F. M. and S. K. conducted the nutritional experiments in fish. S. P. was responsible for project development, drafted the manuscript and is the corresponding author.

There are no conflicts of interest.

\section{References}

1. Food and Agriculture Organization (2006) State of world aquaculture. ftp://ftp.fao.org/docrep/fao/009/a0874e/a0874e00.pdf

2. Gatlin DM III, Barrows FT, Brown P, et al. (2007) Expanding the utilization of sustainable plant products in aquafeeds: a review. Aquaculture Res 38, 551-579.

3. Cho C \& Kaushik SJ (1990) Nutritional energetics in fish: energy and protein utilization in rainbow trout (Salmo gairdneri). World Rev Nutr Diet 61, 132-172.

4. Sargent JR \& Tacon AGJ (1999) Development of farmed fish: a nutritionally necessary alternative to meat. Proc Nutr Soc 58, 377-383.

5. Webster CD \& Lim C (2002) Nutrient Requirements and Feeding of Finfish for Aquaculture. Wallingford, UK: CABI Publishing.

6. Webster C, Lim C \& Lee S-C (2007) Use of Alternative Protein Sources in Aquaculture Diets. Binghampton, NY: The Haworth Press.

7. Francis G, Makkar H \& Becker K (2001) Antinutritional factors present in plant-derived alternate fish feed ingredients and their effects in fish. Aquaculture 199, 197-227.

8. Kaushik SJ (1990) Use of alternative protein sources for the intensive rearing of carnivorous fishes. In Mediterranean Aquaculture, pp. 125-138 [R Flos, L Tort and P Torres, editors]. Chichester, UK: Ellis Horwood.

9. Kaushik SJ, Cravedi JP, Lalles JP, Sumpter J, Fauconneau B \& Laroche M (1995) Partial or total replacement of fish meal by soybean proteins on growth, protein utilization, potential oestrogenic or antigenic effects, cholesterolemia and flesh quality in rainbow trout. Aquaculture 133, 257-274.

10. Watanabe T, Aoki H, Shimamoto K, Hadzuma M, Maita M, Yamagata Y, Viswanath K \& Satoh S (1999) A trial to culture yellowtail with non-fishmeal diets. Fisheries Sci 64, 505-512.

11. Watanabe T, Verakunpiriya V, Watanabe K, Viswanath K \& Satoh S (1998) Feeding of rainbow trout with non-fish meal diets. Fisheries Sci 63, 258-266.

12. Kaushik SJ, Coves D, Dutto G \& Blanc D (2004) Almost total replacement of fishmeal by plant protein sources in the diets for European seabass (Dicentrarchus labrax). Aquaculture 230, 391-404.

13. Gomez-Requeni P, Mingarro M, Calduch-Giner JA, Medale F, Martin SAM, Houlihan DF, Kaushik S \& Perez-Sanchez J (2004) Protein growth performance, amino acid utilisation and somatotropic axis responsiveness to fish meal replacement by plant protein sources in gilthead sea bream (Sparus aurata). Aquaculture 232, 493-510.

14. Vilhelmsson OT, Martin SAM, Medale F, Kaushik SJ \& Houlihan DF (2004) Dietary plant protein substitution affects hepatic metabolism in rainbow trout. Br J Nutr 92, 71-80. 
15. Bell JG, Tocher DR, Henderson RJ, Dick JR \& Crampton VO (2003) Altered fatty acid compositions in Atlantic salmon (Salmo salar) fed diets containing linseed and rapeseed oils can be partially restored by a subsequent fish oil finishing diet. J Nutr 133, 2793-2801.

16. Glencross BD, Hawkins WE \& Curnow JG (2003) Restoration of the fatty acid composition of red seabream (Pagrus auratus) using a fish oil finishing diet after growth-out on plant based diet. Aquaculture Nutr 9, 409-418.

17. Regost C, Arzel J, Robin G, Rosenlund G \& Kaushik SJ (2003) Total replacement of fish oil by soybean or linseed oil with a return to fish oil in turbot (Psetta maxima). Aquaculture 220, 737-747.

18. Richard N, Kaushik S, Larroquet L, Panserat S \& Corraze G (2006) Replacing dietary fish oil by vegetable oils has little effect on lipogenesis, lipid transport and tissue lipid uptake in rainbow trout (Oncorhynchus mykiss). Br J Nutr 96, 299-309.

19. Folch J, Lees M \& Sloane Stanley GH (1957) A simple method for the isolation and purification of total lipides from animal tissues. J Biol Chem 226, 497-509.

20. Moore S \& Stein WH (1951) Chromatography of amino acid on sulfonated polystyrene resin. J Biol Chem 192, 663-681.

21. Govoroun M, Le Gac F \& Guiguen Y (2006) Generation of a large scale repertoire of expressed sequences tags (ESTs) from normalised rainbow trout cDNA libraries. BMC Genomics 7, 196-203.

22. Nguyen C, Rocha D, Granjeaud S, Baldif M, Bernard K, Naquet P \& Jordan B (1995) Differential gene expression in the murine thymus assayed by quantitative hybridization of arrayed cDNA clones. Genomics 29, 207-216.

23. Lopez F, Rougemont J, Loriod B, Bourgeois A, Loi L, Bertucci F, Hingamp P, Houlgatte R \& Granjeaud S (2004) Feature extraction and signal processing for nylon DNA microarrays. BMC Genomics $\mathbf{5}, 38$.

24. Cathelin R, Lopez F \& Klopp C (2007) AGScan: a pluggable microarray image quantification software based on the ImageJ library. Bioinformatics 23, 247-248.

25. Saal LH, Troein C, Vallon-Christersson J, Gruvberger S, Borg A \& Peterson C (2002) Bioarray software environment (BASE): a platform for comprehensive management and analysis of microarray data. Genome Biol 3, software0003.1-software0003.6 (epublication 15 July 2002).

26. Pan W (2002) A comparative review of statistical methods for discovering differentially expressed genes in replicate microarray experiments. Bioinformatics 21, 546-554.

27. Zeeberg BR, Feng W, Wang G, et al. (2003) GoMiner: a resource for biological interpretation of genomic and proteomic data. Genome Biol 4, R28.

28. Rexroad CE III, Lee Y, Keele JW, Karamycheva S, Brown G, Koop B, Gahr SA, Palti Y \& Quackenbush J (2003) Sequence analysis of a rainbow trout cDNA library and creation of a gene index. Cytogenet Genome Res 102, 347-354.

29. Olsvik P, Lie K, Jordal A, Nilsen T \& Hordvik I (2005) Evaluation of potential reference genes in real time RT-PCR studies of Atlantic salmon. BMC Mol Biol 17, 6-21.

30. Pfaffl MW (2001) A new mathematical model for relative quantification in real-time RT-PCR. Nucleic Acids Res 29, 2002-2007.

31. Pfaffl MW, Horgan GW \& Dempfle L (2002) Relative expression software tool (RESTC) for group-wise comparison and statistical analysis of relative expression results in realtime PCR. Nucleic Acids Res 30, 9-36.

32. Sargent JR, Tocher DR \& Bell JG (2002) The lipids. In Fish Nutrition, 3rd ed., pp. 181-258 [JE Halver and RW Hardy, editors]. San Diego: Academic Press.
33. Jump DB, Clarke SD, Thelen A \& Liimatta M (1994) Coordinate regulation of glycolytic and lipogenic gene expression by polyunsaturated fatty acids. J Lipid Res 35, 1076-1084.

34. McGrath ME (1999) The lysosomal cysteine protease. Annu Rev Biophys Biomol Struct 28, 181-204.

35. Mortimore GE \& Kadowaki M (2001) Regulation of protein metabolism in liver. In Handbook of Physiology. Section 7 The Endocrine System. Volume II - The Endocrine Pancreas and Regulation of Metabolism, pp. 553-577 [LS Jefferson and AD Cherrington, editors]. New York: Oxford University Press.

36. Barzanti V, Battino M, Baracca A, Cavazzoni M, Cocchi M, Noble R, Maranesi M, Turchetto E \& Lenaz G (1994) The effect of dietary lipid changes on the fatty acid composition and function of liver, heart and brain mitochondria in the rat at different ages. Br J Nutr 71, 193-202.

37. Buhler DR \& Wang-Buhler JL (1998) Rainbow trout cytochrome P450s: purification, molecular aspects, metabolic activity, induction and role in environmental monitoring. Comp Biochem Physiol 121, 107-137.

38. Jacobs MN, Covaci A, Gheorghe A \& Schepens P (2004) Time trend investigation of PCBs, PBDEs, and organochlorine pesticides in selected $n-3$ polyunsaturated fatty acid rich dietary fish oil and vegetable oil supplements; nutritional relevance for human essential $n-3$ fatty acid requirements. J Agric Food Chem 52, 1780-1788.

39. Jacobs MN, Covaci A \& Schepens P (2002) Investigation of selected persistent organic pollutants in farmed Atlantic samon (Salmo salar), salmon aquaculture feed, and fish oil components of the feed. Environ Sci Technol 36, 2797-2805.

40. Lee SJ \& Buhler DR (2002) Functional properties of a rainbow trout CYP3A27 expressed by recombinant baculovirus in insect cells. Drug Metab Dispos 30, 1406-1412.

41. Pikuleva IA (2006) Cytochrome P450s and cholesterol homeostasis. Pharmacol Ther 112, 761-773.

42. Wool IG, Chan Y \& Gluck A (1994) Structure and evolution of mammalian ribosomal proteins. Biochem Cell Biol 73, 933-947.

43. Meyer A \& Van de Peer Y (2005) From 2R to 3R: evidence for a fish-specific genome duplication (FSGD). Bioessays 27, 937-945.

44. Ishii K, Washio $\mathrm{T}$, Uechi $\mathrm{T}$, Yoshihama M, Kenmochi N \& Tomita M (2006) Characteristics and clustering of human ribosomal protein genes. BMC Genomics 7, 37.

45. Essex-Fraser PA, Steele SL, Bernier NJ, Murray BW, Stevens ED \& Wright PA (2005) Expression of four glutamine synthetase genes in the early stages of development of rainbow trout (Oncorhynchus mykiss) in relationship to nitrogen excretion. J Biol Chem 280, 20268-20273.

46. Labow BI, Souba WW \& Abcouwer SF (2001) Mechanisms governing the expression of the enzymes of glutamine metabolism glutaminase and glutamine synthetase. J Nutr 131, Suppl. 9, 2467S-2474S

47. Wicks DJ \& Randall BJ (2002) The effect of sub-lethal ammonia exposure on fed and unfed rainbow trout: the role of glutamine in regulation of ammonia. Comp Biochem Physiol 132B, 275-285.

48. Jordal AE, Torstensen BE, Tsoi S, Tocher DR, Lall SP \& Douglas SE (2005) Dietary rapeseed oil affects the expression of genes involved in hepatic lipid metabolism in Atlantic salmon (Salmo salar L.). J Nutr 135, 2355-2361.

49. Salem M, Silverstein J, Rexroad CE III \& Yao J (2007) Effect of starvation on global gene expression and proteolysis in rainbow trout (Oncorhynchus mykiss). BMC Genomics 8, 328.

50. Naylor RL, Goldberg RJ, Primavera JH, Kautsky N, Beveridge MCM, Clay J, Folke C, Libchenko J, Mooney H \& Troell M (2000) Effect of aquaculture on world fish supplies. Nature 405, $1017-1024$. 